\title{
Evidentiality in the Samoyedic languages: A study of the auditive forms
}

\author{
Eleonora Usenkova \\ Department of English, University of Saskatchewan \\ eleonora_usenkova@mail.com
}

\begin{abstract}
In the Samoyedic languages non-visuality is marked by the affixes of a specific Auditive mood that is explored in this paper from paradigmatic and syntagmatic perspectives. The focus is on various usages of the Auditive in its paradigmatic meaning, as well as on correlation of the meaning of this mood with the semantic properties of the predicates it marks. The work also examines the emergence of the Auditive in the functional sphere of other moods, the use of other moods as functional equivalents of the Auditive, and the semantic grounds for these transpositions.
\end{abstract}

Keywords: Auditive mood; non-visual evidentiality; category of perception; modality; morphosyntax

\section{Preliminaries and key concepts}

\subsection{Background: Samoyedic languages}

The Samoyedic languages, together with the Finno-Ugric languages, constitute the Uralic family, which covers a vast area of northern Eurasia. They are traditionally divided into two major branches: Northern Samoyedic and Southern Samoyedic. Nenets (Yurak), Enets (Yenisei-Samoyed), and Nganasan (Tawgy) belong to the Northern Samoyedic languages. Geographically, Nenets is spoken along the Arctic coast from the White Sea region to western Taimyr; Enets speakers occupy the area in the lower Yenisei region; Nganasan is spoken on the Taimyr Peninsula from the lower Yenisei in the west to the Khatanga Bay in the east (Janhunen 1998, 457). The Southern branch is represented by only one living language - Selkup (Ostyak-Samoyed), which is spoken in the region between the Ob' and Yenisei from the Taz and Turukhan in the north to the Chaya and Chulym in the south. The other Southern Samoyedic languages, Mator (Motor) and Kamas (Kamassian), became extinct in about 1840 and 1989, respectively, without being fully documented (Janhunen 1998, 457; Helimski 2001, 176; Marcantonio 2002, 1). All the Samoyedic languages 
are endangered: Southern Selkup and Enets are on the brink of extinction; Northern Selkup, Forest Nenets, and Nganasan are approaching the borderline of viability. Even Tundra Nenets (with some 25,000 speakers) can also be viewed as potentially endangered (Helimski 2001, 176).

The Northern and Southern Samoyedic languages are further split into dialects. There are two very close dialects in Nganasan: Avam and Vadey. Enets discriminates between Tundra and Forest dialects. Similarly, Nenets is divided into Tundra Nenets and Forest Nenets, which in Samoyedology are traditionally regarded as dialects though some scholars prefer to treat them as separate languages rather than dialects, but this is largely a matter of taste and terminology (Helimski 2001, 188). Selkup falls into two large language areas: Northern (Taz-Yenisei) and Southern (Tym-NarymKet-Ob') (Kuznetsova 1995, 5). These dialects form a continuum; the differences between two adjacent dialects are minimal but the ends of the continuum, represented by the Taz and Ob' idioms, are mutually incomprehensible (Helimski 1998b, 549).

The morphology of the Samoyedic languages is principally agglutinative, with suffixation dominant in both derivation and inflexion; prefixes are not used at all. Ideally, agglutination means that a grammatical category is expressed with a clearly segmentable and invariant morpheme; a word may consist of more than one morpheme, but the boundaries between morphemes are always clear cut. The criterion of segmentability of morphemes is crucial in treatments of agglutination, whereas the criterion of phonetic invariance of morphemes is important for comparing agglutination with the opposite morphological technique, known as fusion (Comrie 1981, 43). A considerable amount of grammatical data, analyzed by Samoyedologists over the past several decades, reveals that the Samoyedic languages, besides agglutinative, demonstrate inflectional characteristics as well (Wagner-Nagy 2011, 4). Fusion usually means that the expression of different grammatical categories within a word is fused together to form a single, unsegmented morph; the boundaries between morphemes cannot be easily delineated (Comrie 1981, 48). In all the Samoyedic languages, fusion is mostly (but not exclusively) associated with a high degree of morphophonological alternations of exceptional complexity, both radical and suffixal, when certain grammatical word forms are built. Although synthesis predominates in the expression of grammatical meanings, a few analytical constructions are also ascertained in the Samoyedic languages. Overall these analytical constructions do not appear to be stable and can easily be transformed into synthetic ones, which additionally speaks to the existence of a strong tendency to synthesis. Despite the fact that fu- 
sion in the Samoyedic languages have not yet become the subject matter of specific research, typological observations made in the grammatical descriptions of the southern dialects of Selkup, Tundra Nenets, and Nganasan unanimously point out that fusional properties manifest themselves more notably when a word is greatly affected by phonetic processes triggering changes in its structure (Helimski 1998a, 487; Zyrjanova 2001, 5; Burkova 2010, 232; Nikolaeva 2014). Regrettably, this compelling typological aspect has not been even mentioned or touched in Forest Nenets and Tundra Enets grammar works, to a large extent, due to scarcity of the documented materials and, as a result, insufficient linguistic investigtion.

The major word classes in the Samoyedic languages are nouns and verbs; they share the grammatical categories of number and person. Nouns are declined for number (singular, dual, and plural) and case (nominative, genitive, accusative, dative, locative, ablative, prolative). The three types of noun declension are absolute, possessive, and (pre)destinative. Nouns also have a set of predicative endings. Verbs are conjugated according to the subjective, objective, and reflexive types in Northern Samoyedic languages; in Selkup there are only two conjugation types: subjective and objective. The central category for verbs is mood. The importance of the data from these languages for cross-linguistic studies on verbal modal categories lies in the fact that they possess unusually ramified sets of forms for rendering different types and shades of modal or modal-temporal meanings: 16 moods are mentioned in Nenets (Salminen 1997, 98); 12 moods in Nganasan (Helimski 1998a, 503), 11 moods in Enets (Mikola 1995, 21), 8 moods in Selkup (Helimski 1998b, 566), but this list is most likely not exhaustive. The category of tense (aorist/present, past, future) is distinguished only in some of the moods. Among the Samoyedic languages only Selkup has the inflectional category of aspect, with a distinction between perfective and imperfective (Kuznetsova et al. 1980, 217-218; Kuznetsova 1995, 20); for the Northern Samoyedic languages it is preferable to speak of the Aktionsarten (iterative, durative, intensive, inchoative, attenuative, frequentative, etc.). Non-finite forms of the verb include infinitives, participles, gerunds, and the connegative.

In their inflection adjectives, numerals, and most pronouns do not differ from nouns. Personal pronouns, adverbs, and postposions comprise minor word classes of their own (Salminen 1997, 91). Syntactically, the Samoyedic languages are patterned as typical SOV languages. Within the noun phrase the attribute preceeds its head. Negation is formed analytically by means of an auxiliary negative verb which takes some derivational and all the inflectional markers, as well as negated lexical verbs in the connegative form. 
Perhaps the most challenging problem in presenting examples of a typological research on Samoyedology is the absence of unified orthography and transcription for all the languages of this family. Despite the fact that scientifically grounded systems of notation and transcription have already been developed and are currently being employed for individual languages (Nenets, Nganasan, and Selkup), there exist fundamentally unbridgeable discrepancies among all the existing orthographic and transcription traditions. In this paper, there has been made an endeavour to apply FinnoUgric transcription in order to facilitate reading of the examples and make the paper accessible to a wide range of linguists (Lytkin 1960; Vende 1967).

\subsection{Evidentiality}

Evidentiality is the most recent and truly mesmerizing discovery in grammar, which currently enjoys an ever-increasing attention on the part of linguists. A growing number of studies of this category in various languages all over the globe have made it possible to conduct its cross-linguistic typological investigation, gather diverse terminology together, and elaborate a thoroughly defined terminological inventory. In this work, terminology on the category of evidentiality proper will be used in accord with the mainstream typological research.

"Evidentiality is a grammatical category that has source of information as its primary meaning - whether the narrator actually saw what is being described, or made inference about it based on some evidence, or was told about it, etc." It is "a verbal grammatical category in its own right, and it does not bear any straightforward relationship to truth, the validity of a statement, or the speaker's responsibility" (Aikhenvald 2006, 320). Evidentiality is not a subcategory of any modality or of tense-aspect (Aikhenvald 2004a, 7). It has been established that evidentiality embraces the following five semantic parameters: visual, sensory, inference, assumption, reported, and quotative. The ability of these semantic parameters to group together in various ways results in discerning a substantial variability in the evidential systems in different languages. Thus, the simplest evidential system includes two semantic parameters, while the richest ones may be based on five or more.

According to an alternative perspective, an evidentiality system may or may not specify the exact information source, in which case it distinguishes direct and indirect evidentials (Aikhenvald \& Dixon 2014, 9). This implies that these two subcategories of evidentiality are also opposed to each other by the feature of personal involvement of the observer in the 
designated situation. The term 'indirect' denotes that the speaker did not witness the action or event; the information was acquired from an indirect information source (Haarmann 1970, 23). Indirect evidentiality covers the semantic parameters of inference (visible or tangible evidence or result), assumption (evidence other than visible result: logical reasoning, assumption, or even general knowledge), reported evidentials (reported information with no reference to who it was reported by), and quotative evidential (reported information with an overt reference to the quotative source) (Aikhenvald 2004a, 394). It should be noted that, besides the terms 'reported' and 'quotative' evidentials, Samoyedologists also widely resort to a more general term 'renarrative' evidential, which indicates reported information regardless reference to its source. Direct evidentiality denotes that "the speaker has some sensory evidence for the action or event he/she is describing" (De Haan 2008). The speaker's knowledge is qualified as complete, adequate, and reliable, providing that the stipulation of sincerity has been fulfilled. Direct evidentiality covers visual and sensory semantic parameters. Visual evidentiality implies information acquired through seeing, whereas non-visuality covers information acquired through hearing, smelling, tasting, feeling, and sometimes also touching something (Aikhenvald \& Dixon 2014, 9). Some scholars claim that the meaning of non-visuality emerges in language relatively late (Serebrennikov 1964, 157; De Haan 1998). Indeed, forms expressing non-visuality have not been registered in the already-extinct Sayan-Samoyedic languages, nor do the Finno-Ugric languages have such forms (Tereschenko 1979, 221).

In the Samoyedic languages evidentiality is expressed by verbal inflectional morphology. The evolution of specific morphological forms expressing evidential meanings in these languages seems to be an areal phenomenon: "there is a wide Eurasian areal-typological area (including Uralic - Finno-Ugric and Samoyed - languages), using wide-scale evidentiality systems and strategies. Many of them are common for Uralic (especially Samoyed), Paleosiberian (Paleoasiatic) and Altaic languages. Possibly this area extends itself to the south-eastern Asia (e.g., Sino-Tibetan et al. languages)" (Künnap 2002, 152).

Evidentiality currently is a popular topic among Samoyedologists: there are a number of works devoted to the description of evidentiality that in general quite clearly reflect the present state of theoretical knowledge about this category (Iljina 2002; Künnap 2002; Burkova 2004; 2010; Kuznetsova \& Usenkova 2004a;b; 2006; Gusev 2007; Ljublinskaja \& Maljčukov 2007). 


\subsection{Modality}

In the Samoyedic languages, verbal moods are a morphological means of simultaneously expressing evidentiality and modality. In this paper, modality is defined as a category in whose semantic content there can be distinguished several meanings or aspects:

Internal modality is the relationship of the subject/object of the action to the performed action; for the object it is the relationship of the subject to the action which it undergoes. This type of modal relationship reflects an assessment of the connection between the subject/object of factuality and the feature assigned to it according to the mode of existence of this relationship: whether that be possibility, necessity, or desirability.

External objective modality is the relationship of the sentence content to factuality in the plane of reality/irreality. This type of modality is an obligatory characteristic of any utterance. It is one of the categories that forms a predicative unit - a sentence.

In the system of moods, real actions are those which not only were performed or are being performed within a designated period of time, but also are actions, the reality of whose performance is possible, necessary, desirable (internal modality), or only supposed (elements of irreality).

The core of reality is actuality. It reflects the existence which does not contain any elements associated with such modal meanings as irreality, potentiality, unreliability, 'somebody else's experience', etc. The meaning of actuality finds its immediate expression in the situation of the Actual Present, which is the situation ' $\mathrm{I}$ - now - here - this'. The Actual Present denotes the highest degree of reality that is experienced, perceived, concrete, and evident (Bondarko 1990a, 72).

Irreality/hypotheticality denotes - from the point of view of the speaker - a supposed action which in a particular context acquires various modal and expressive-emotional overtones: wish, encouragement, contrition, etc. (Shentsova 1998, 35-37). The conditional character of performing this action - that is, dependence on some conditions, causes, situation - is implied, but is not expressed by lingual means. The action is spoken of as if it existed in factuality but only conditionaly. If the sentence contains a definite condition, cause, or situation the action is interpreted as being real (Ermolaeva 1987, 70).

Irreality is connected with reality through the sphere of potentiality, which includes unreality; because of this connection between reality and irreality in their qualitative distinctness, there exist gradual transitions' (Bondarko 1990a, 75). The integral meaning of potentiality covers vari- 
ous categorial meanings of external objective modality (imperativity, optativity, hypotheticality, conditionality) and external subjective modality (possibility, necessity, reliability, obligatoriness, intentionality), and can accompany utterances of different communicative types.

Unreal actions are actions that either were not performed or are not being performed within a designated period of time-implied negation is an objective factor, but these actions are spoken about in a conditional manner, as if they had been performed or were being performed-i.e., absence of direct indication of negation.

External subjective modality combines the meanings of external objective modality and the assessment of an utterance by its producer. The semantic components of this modality - reliability, possibility/impossibility, obligatoriness, and intentionality - supplement the basic characteristics of external objective and communicative modalities. The semantic content of external subjective modality also includes the notion of assessment as well as various kinds of emotional (that is irrational) reaction.

Communicative modality covers the meanings of declaration, interrogation, and inducement.

Emotive modality embraces expressive/non-expressive utterances. Emotivity expresses subjective reactions of the speaker and as such is closely connected with expressivity and assessment.

Any of these five aspects of modality can be expressed by morphological means. This specifies why the semantic content of the category of mood in different languages does not coincide (Ermolaeva 1987, 12). Therefore, the definition of the category of mood must be quite broad and must enable specification for particular languages in different periods of their developments. Thus, mood is defined as "an inflectional category of the verb that can express various kinds of modality" (Kuznetsova 1995, 73).

\section{Evidential moods in the Samoyedic languages and morphology of the Auditive}

The following evidential moods have been discriminated in the Samoyedic languages:

- Nganasan: Auditive, Renarrative, Inferential (Helimski 1994; Usenkova 2002; Kuznetsova \& Usenkova 2004b).

- Nenets: Auditive, Inferential, Similative (Approximative), Probabilitive (Verbov 1973; Labanauskas 1981; Perrot 1996; Salminen 1997; 
Kuznetsova \& Usenkova 2004a; 2006; Ljublinskaja \& Maljčukov 2007).

- Enets: Auditive, Reported (Narrative), Inferred (Probabilitive) (Künnap 2002).

- Selkup: Latentive (Inferential, Narrative), Auditive (Collinder 1957, 469; Kuznetsova et al. 1980, 235-248; Cheremisina \& Martynova 1991, 10-13; Helimski 1998b, 566).

Unlike Northern Samoyedic languages - Nganasan, Nenets, Enets - where Auditive forms are still widely used, in Southern Samoyedic Selkup Auditive forms are already regarded as archaic. Only few instances of these forms could be found in folklore texts and in written records made in earlier years.

It is worthy of note that the subject of the verb in Northern Samoyedic Auditive forms is marked by suffixes, which are connected through their origin with the personal possessive affixes (Prokofjev 1937, 44; Collinder 1957, 442; Verbov 1973, 100; Tereschenko 1979, 220). This fact has caused significant disagreement among scholars regarding the nature of the Auditive. In relevant literature, it is treated as a non-finite form (for example, the subordinate), for "it cannot combine with the category of conjugation" (Salminen 1997, 115; Salminen 1998a, 25), or is included in the list of verbal moods due to the peculiarities of its semantics and functioning (Collinder 1957, 441; Verbov 1973, 100; Helimski 1994, 205; Sorokina \& Bolina 2005).

In Nenets, the Auditive suffixes are -wo'- (-won-, -wono-), -wononand -mo'- (-mon-, -mono-), -monon- (Kuprijanova et al. 1985, 170). In

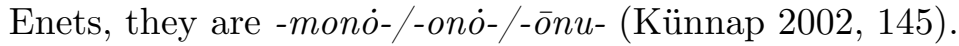

In both languages, the Auditive markers are placed between the verbal stem and affixes of the agent (Prokofjev 1937, 44; Tereschenko 1973, 145; Kuprijanova et al. 1985, 170; Kanakin 1996, 31).

Nganasan has two variants for morphologically marking the Auditive: "as a non-finite form it is represented by the model S1-MUND-Px2, and as a mood by the model S1-MUND-Vx and S1-MUNI-Vx (S1-MÜNI-Vx), where $\mathrm{S} 1$ is an infinitive of the verb regarded as the initial form of a stem; Px2 is personal possessive inflections; Vx is personal verbal inflections" (Helimski 1994, 201, 212, 221).

In Selkup, the Auditive is marked by the suffixes $-k u n(\mathrm{~V})-/-k y n(\mathrm{~V})$. These suffixes are placed between the verbal stem and inflections which are identical to the affixes of the Conditional mood. Consequently, the Selkup Auditive belongs to the conjugated forms (Prokofjev 1937, 44; Prokofjeva 
1966, 408; Tereschenko 1973, 145; Kuznetsova et al. 1980, 247; Kuprijanova et al. 1985, 170; Kanakin 1996, 31; Helimski 1998a, 568).

All Samoyedic non-visual sensory evidentials are etymological cognates. Prominent Samoyedologist Künnap proposes the following explanation of their origins:

"the Enets auditive suffix -mono-, etc. may be regarded as a result of grammaticalization of the Common Samoyedic substantive *mun $(? \sim *$ mon $)$ 'voice' or of a verb that formally more or less coincides with the former. In this case the respective grammaticalization has probably taken place in all three Northern Samoyedic languages, since the Auditive suffix in Nenets is -mo'-/-mon-/- $\beta o^{\prime}-/$ - $\beta$ on-, etc. and in Nganasan -munu-/-mini-, etc. Among South-Samoyed languages the auditive is known only in Selkup with the suffix -kunä-/-kuni-, etc. [...] through the sound shift $\beta>k \beta>k$ the latter might share a common origin with the Northern Samoyedic suffix or it may have been derived from the word $k u$ - 'ear; to hear'."

(Künnap 2002, 151)

\section{Semantic characteristics of the Auditive}

\subsection{Paradigmatic meaning of the Auditive}

The paradigmatic meaning of the Auditive mood is reality (in particular, actuality), complicated by the meaning of non-visual perception. The Auditive is only realized in declarative sentences where its main communicative function is statement of facts. It appears that the Auditive can only be used in declarative sentences due to lack of interest or concern on the part of the speaker regarding the perceived action or event. The speaker expresses neither inducement nor a question, since the situation is known; everything that is happening, the speaker perceives in person: ${ }^{1}$

${ }^{1}$ The following grammatical abbreviations are used: $1=$ first person; $2=$ second person; $3=$ third person; $\mathrm{ABS}=$ absolute declination; $\mathrm{ACC}=$ accusative case $; \mathrm{ALL}=$ allative case; $\mathrm{APPROX}=$ the Approximative mood; $\mathrm{ATTEN}=$ attenuative; $\mathrm{AUD}=$ the Auditive mood; $\mathrm{AUGM}=$ augmentive $; \mathrm{CONNEG}=$ connegative $; \mathrm{CONT}=$ continuous aspect; $\mathrm{DAT}=$ dative DEST $=$ destinative $; \mathrm{DIM}=$ diminutive $; \mathrm{DU}=$ dual number $; \mathrm{DUR}=$ durative; $\mathrm{EL}=$ ellative case $; \mathrm{GEN}=$ genitive case $; \mathrm{GRAD}=$ graduative $\mathrm{IMP}=$ the Imperative $\operatorname{mood} ; \mathrm{INCH}=$ Inchoative; IND $=$ the Indicative mood; INFERR $=$ the Inferrential; IN$\mathrm{STR}=$ instrumental; INTEN $/ \mathrm{PERF}=$ intensive $/$ perfective; INTERR $=$ the Interrogative mood; ITER $=$ iterative; $\mathrm{LAT}=$ lative case LATENT $=$ the Latentive mood $;$ LOC $=$ locative case $\quad \mathrm{NOM}=$ nominative case $; \mathrm{O}=$ objective conjugation; $\mathrm{PERF}=$ perfect; $\mathrm{PL}=$ plural number; POSS $=$ possessive; POSTP $=$ postposition; PRAES $=$ present $;$ PROL $=$ prolative case; $\mathrm{PROLADV}=$ prolative in nominal adverbials; $\mathrm{PRTCL}=$ particle; $\mathrm{PTPAST}$ $=$ past participle; PTPRAES = present participle; $\mathrm{R}=$ reflexive (objectless) conjugation; $\mathrm{RES}=$ resultative; $\mathrm{S}=$ subjective conjugation; $\mathrm{SG}=$ singular number; $\mathrm{VAINF}=$ verbal adverb; VACOND $=$ conditional verbal adverb; VNIMPF $=$ imperfective verbal noun 
(1) Nganasan

Нәмыðың мунумунуч'у - мона н'имбы диӓ уъмӨакуðам.

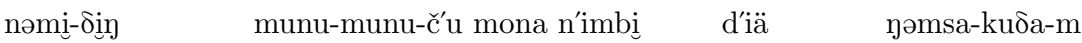

mother-POSS.3.PL say-AUD-3.SG I adult[-ACC] brain[-ACC] eat-IMP-1.SG.S

'Their mother is heard saying, "I will eat the brain [of the] adult."' (Porotova 1980, 8)

(2) Nenets

Сидя хасавар харти' поргананди' тэдосумбвонди'.

s'id'a hasaßa-r hart'if

two man-Poss.2.sG two.of.them.by.themselves

pongana-nd'if tedosu-mb-ßon-d'if

between.something-POSS.3.DU squabble-DUR-AUD-3.DU

'Two men are heard squabbling.'

(Tereschenko 1990, 237)

(3) Enets

Мамноза: "Кас-кас̧е, одъи омлуйбь."

ma-mno-za kas-kas'e odei omluj- $\emptyset$-b'

say-AUD-3.SG kas-kase odej feel.hungry-IND.PRAES-1.SG.R

'[The witch] is heard saying, "Kas-kase, odej, [how] hungry I feel."

(Sorokina \& Bolina 2005)

(4) Selkup

Šērkunänti.

šēr-kunä-nti

enter-AUD-2.SG.S

'You are heard entering.'

(Künnap 1978, 98)

A verb marked by an Auditive affix specifies that the action is real. Thus, the Auditive expresses external objective modality. It is characteristic of the Auditive to express reality in a narrow sense - as actuality, which is frequently associated with the Actual Present. In the Samoyedic languages, with the exclusion of Tundra Nenets, temporal differentiation is not materially expressed by the Auditive, and context plays a major role in determining temporal information. As to the Tundra Nenets Auditive, it has present and past; the past is formed with the regular past tense affix of finite verbs -s'ว (Nikolaeva 2014, 113).

(5) Nganasan

Бон'д'и уонӨыд'и н'ад'иџаџку нын'ӧ өиги? ин'иӓмты маðакад'а уонөу? иðа д'иlөитиөи. МаðакунӨыны Өиги? ин'иӓ н'ӧтынану һид'ити? . Н'емыðыу мунумунуч'у мона н'имбы д'иӓ ђъмӨакуðам. 
bon'd'i yonsi-d'i n’ad'ina-yku nin'o

outside go.out-VAINF Nganasan.woman-DIM daughter

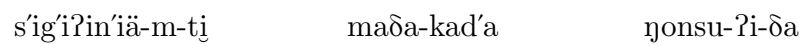

cannibal-ACC-POSS.3.SG tent[-GEN]-near[-ALL] stop-IND.PRAES.PERF-3.SG.R

d'ils'i-t'i-s'i maóa-kunsi-ni s'igi?in'iä

listen-IND.PRAES.CONT-3.SG.R tent[-GEN]-inside-LOC cannibal

n'o-ti-nanu h'id'i-t'i-?

child[-GEN]-POSS.3.SG-with[-LOC] laugh-IND.PRAES.CONT-3.PL.S

n'emi-oing munu-munu-ču mona n'imbi

mother-POSS.3.PL say-AUD-POSS.3.SG I adult[-ACC]

d'iä yəmsa-kuסa-m

brain eat-IMP-1.SG.S

'Having come outside, the daughter of the Nganasan woman has stopped at the tent of a cannibal, she is listening. Inside the tent the cannibal and her daughters are laughing. ... Their mother is heard saying, "I will eat the brain of an adult.""

(Porotova 1980, 8)

(6) Nenets

Мадорота яха варан тэврихива, маниебнани, сидя хасаваха' ёрмэхэ'. Амгэ пиркана няби хасава сими монэтакы, няханта мамононта: "Маядорта не уэрханю."

madorota jaha $\beta$ ara-n te $\beta r^{\prime}$ ih'i- $\beta$ a

twisting river edge-DAT come.to-VNIMPF

man'ije-b-nan'i s'id'a hasaßa-haf

see-VACOND-POSS.1.SG two man-DU

jor-me-hef amge p'irkana n'ab'i hasaßa

fish.with.net-PTPAST-3.DU.s after.some.time other man

s'im'i mane-ta-ki- $\emptyset$ n'a-han-ta ma-monon-ta

I[-ACC] see-PRAES-INFERR-3.SG.S friend-DAT-POSS.3.SG say-AUD-POSS.3.SG

majadorta n'e ye- $\emptyset$-rha- $\emptyset=n^{\prime} u$

suffering woman be-PRAES-APPROX-3.SG.S=PRTCL

'When I came to the bank of a twisting river, I saw two men fishing with a net. After some time one man, evidently, saw me, he is heard saying to his friend, "She seems to be a suffering woman."

(Labanauskas 2001, 105)

(7) Enets

Инэй миггорио ние му", каре то аборихозо сэкораза. Инэй лэумунзо': Пебей, ши литора"!

inej m'iggor'io n'ie- $\emptyset-\emptyset \quad$ mu-? kar'e

elder.brother nothing not-IND.PRAES-3.SG.S do-CONNEG fish

to- $\emptyset-\emptyset \quad$ abor'i-hozo sekora- $\emptyset$-za inej

show.up-IND.PRAES-3.SG.S head-EL seize-IND.PRAES-3.SG.O elder.brother 
leu-mun-zof p'eb'ej ši l'itora- $\emptyset-$ ?

shout-AUD-3.SG younger.brother I[-ACC] save-IMP-2.SG.S

'The elder brother has not done anything, the fish has shown up [and] seized his head. The elder brother is heard shouting, "The younger brother, save me!"'

(Labanauskas 1992, 13)

The Actual Present is an actually experienced "real time", unlike reality that is restored from memory or reality projected to the future. As a rule, it shows itself most vividly in narratives about past events.

(8) Nenets

Поб" мэва' пыда тунисавэй' пэдара' помна ядвысь. Пон' ядвысь, пэдавыць. ... Лэркабт' ханена мунм' намда: «Дзен-н» - уамгэхэва ууркадавонда.

nob? meßaf pida tun'i-saßejf pedara- $\{$ pomna

one time he gun-with forest-GEN through

jad- $\beta \mathrm{i}-\mathrm{s}^{\prime} \quad$ ponf jad- $\beta \mathrm{i}-\mathrm{s}^{\prime}$

wander-PTPAST-3.SG.S for.long.time wander-PTPAST-3.SG.S

peda- $\beta$ i-c' lerkabtf han'ena mun-mf

get.tired-PTPAST-3.SG.R suddenly hunter sound-ACC

namda- $\emptyset-\emptyset$ 亏̌enn namgeheva yurkada-ßon-da

hear-IND.PRAES-3.SG.S dzen-n something strike.with.ringing-AUD-3.SG

'Once he [a hunter] was wandering with his gun through the forest. He was wandering for a long time, he got tired. ...Suddenly the hunter hears a sound, "Dzen-n," something is heard striking with ringing."

(Kuprijanova et al. 1985, 196)

As mentioned earlier, semantically the Auditive functions in the sphere of direct evidentiality that expresses non-visual perception. In itself, perception is recognized as a universal aspect of human experience. An important component of perception is the observer/perceiving subject: it is from the observer's point of view that lingual presentation of perceived events and phenomena is made. This lingual presentation, which involves the use of specific lingual means, may reflect two kinds of knowledge about the world: phenomenological, acquired with the help of sense-organs and regarded as primary, and structural, which is a conceptually structured generalized experience of a linguistic community. The structural knowledge is available for a speaker in a ready-made form (Kravchenko 1996). In situations perceived by an observer, perception ensures direct sensory orientation in the outer world, and as such is not the content of the utterance but rather the reference point of a specific channel of information. In this orientation-formative aspect, discrimination between sensing and feeling is irrelevant for perception: both specify the reference point in the same way (Matkhanova 2000, 79). Non-visual perception in this 
case covers various types of perception: exteroceptive (auditory, tactile, gustatory, and olfactory), interoceptive (information acquired through internal organs, 'gut' feelings, intuition), and proprioceptive (information acquired through the position, location, orientation, and movement of the body and its parts). When non-visual perception encodes phenomenological knowledge, it could be characterized as nontargeted, passive, and uncontrolled. These characteristics of non-visuality as well as heterogeneity of its immediate content - perception - have already been noted in the recent typological literature: "non-visual often implies that the speaker was not in control, or did something involuntary and is generally unsure of what is happening". Non-visual evidentiality "covers evidence which was heard and sometimes also information obtained through senses other than hearing such as taste and smell, and also cognitive processes" (Aikhenvald 2004b, 10).

It appears that non-visual perception is closely connected with the notional category of purpose, which is realized in a language system either as the purpose of communication (intentionality) or as purposefulness of an action; the latter specifies a person's conscious and free self-direction. Communicative intention, as an act of directedness of consciousness, is designed by the speaker for verbal expression; purposefulness of the action consists in communicating the verbal meaning of the purpose. In a broad sense, the meaning of purposefulness presupposes conscious activity by a subject towards achieving the result anticipated in the mind. Within the category of purpose the semantics of purposefulness is opposed to the semantics of non-purposefulness, which denotes that the purpose may be presented as a future state, emotion, or destination, or signals that the purpose has not taken a clear shape yet, which means that it has not received its activity-based expression and still remains in the passive phase of intention.

Non-visual perception is based on the semantics of non-purposefulness, the original meaning of which can be defined as 'general sense' - that is, without reference to sense-organs. General sense is viewed as bodily knowledge: "perception from the impressions of the states of the body (muscle senses, hunger, fatigue, any kind of pain, etc.)" (Potebnja 1993, 50). It is from the meaning of 'general sense' - human knowledge directed into one's own self - that the meaning 'perception by the senses' then develops; it includes all specific kinds of perception except the visual.

It is worth noting that the possibility of non-visual evidentiality having been developed from the broad semantics 'seem, be perceived, feel' has been also recorded in East-Tucanoan languages (Aikhenvald 2003, 20). 
Compare the above with a somewhat similar state of affairs concerning the reflexes of the Indo-European root ${ }^{*} k e u$, meaning 'follow somebody/someone, be guided by somebody/something' ('observe', 'notice', 'perceive', 'contemplate'). In the Indo-European languages the reflexes of this root originally meant 'hear', 'feel (recognize by sensing)', 'notice', 'conceive', 'understand'. However, at a later stage they quite regularly show the development of more specified meanings, i.e., 'hear' and 'perceive by the sense of smell' (Pokorny 1959, 587-588).

Non-visual forms typically express passive perception of a sound, smell, touch, image, etc., without deliberately using a corresponding senseorgan. The process of perception happens in the direction from what is perceived to the perceiving subject and occurs either with the observer's involuntary participation or regardless of the observer's intentions. The feature of uncontrollability over a situation of perception manifests itself in the fact that in this situation, the perceiving subject appears to be the subject of involuntary activity, which implies the absence of any object of intention and which is not definable by the result of the preceding action. Perception appears to be a resultative perceptual state, in which the perceiving subject not only feels the effect of the perceived object on the sense-organ(s) but also conceives this effect. Thus, the resultative perceptual state could be viewed as realization of perception: the object is heard, is felt by smell, taste, touch, etc., which means that the given object is perceived.

In the Samoyedic languages, non-visuality is morphologically expressed only by the Auditive. Comparatively little attention has been given to the description of these forms in Samoyedology. There are no comprehensive works totally devoted to this issue, though practically every description of the Samoyedic grammar does mention the existence of the Auditive forms. In Nganasan, the Auditive forms "denote, except for perception by hearing, the actions which characterize perceptions of some other kinds" (Tereschenko 1979, 221); more exactly, "perceptions by some other senseorgans, for transmitting internal feelings and in general the events that happen with the speaker or the hero of the narrative but which they can neither see nor hear" (Gusev 2007, 422). "The Auditive forms also can be encountered where it would be logical to expect the Renarrative (Quatative) form" (ibid., 423). In Nenets, scholars have noted that the Auditive expresses "the action or state that is not perceived visually, but is determined only with the help of sense-organs - by hearing, smell, touch - or other feelings" (Kuprijanova et al. 1985, 219). In relation to the Enets language, it has been pointed out that "the Auditive chiefly has the same 
meanings as in Nenets" (Tereschenko 1973, 145). However, according to later comments, the Auditive in Enets is concerned "only with auditive perception"; "the incidence of the perception of other senses is based on the statements of researchers alone" (Künnap 2002, 145). Finally, Selkup linguists almost unanimously claim that the Auditive form is restricted to describing actions perceived only by hearing (Tereschenko 1973, 146; Künnap 1978, 96) or that "the existence of that action is inferred from what one hears with one's own ears" (Collinder 1957, 469).

Overall, the above valuable observations regarding the Auditive semantics make it clear that the main evidential meaning of the Auditive is associated with information acquired through hearing. Other meanings of the Auditive have also been documented. It can express other kinds of perception, namely, exteroceptive (sensations by touch and smell) and interoceptive (internal feelings); in Nenets and Nganasan, the Auditive can also be used in an indirect evidential meaning of renarrativity in specific contexts. However, existing treatises on Samoyedic grammar reveal that Samoyedologists treat the meaning of the Auditive forms very cautiously, restricting themselves to superficial comments. The limited treatment to date is the motivation to address this issue in more depth, to explore the combinatorial possibilities of the Auditive and the semantic peculiarities of its functioning in various contexts.

\subsection{Lexico-semantic restrictions of the Auditive use}

In all Samoyedic languages, the Auditive affixes mark the predicates of both active/actional and non-active/non-actional semantics.

The predicates of active semantics imply the presence of intention and control, coming from the subject. Actions expressed by these verbs are, as a rule, accompanied by corresponding sounds which the perceiving subject is able to recognize by hearing. When information about the sounds accompanying this or that action is not part of the word's semantics, then knowledge of realias, what the things and situations around us are, comes to the fore. This knowledge is common for all native speakers of a particular language.

\subsubsection{Semantic classification of predicates marked by the Auditive}

The Auditive forms can be used with the active verbs that denote:

I. Actions closed on the subject.

A. Non-terminative action verbs with the semantics of: 
1. Sounding and speaking. This group of verbs is characterized by a tight link with the subject-source, which produces specific sounds. Concrete animate subjects (human beings and other mammals, birds, and various other creatures) normally function as sources of sounds.

Nganasan: lag'ia?si 'to bark (about a dog, fox, polar fox)'; munud'a 'to speak', 'to talk'.

(9) Тәмәәны, тәмәәны! Хотәрыә мунумунә.

tə-məəni tə-məəni hotəriə munu-munə- $\emptyset$

this-PROLADV this-PROLADV Hotarye speak-AUD-3.SG.S

'Tamaany, tamaany! Hotarye is heard speaking.'

(Helimski 1994, 61)

Nenets: madarc' 'bark (about a dog, fox, polar fox)'; lătărc' 'produce quick interrupted sounds', 'cluck' (about a partridge); turoc' 'grunt (about a reindeer)'; lahanas' 'speak', 'talk'; n'unăbt'os' 'mumble'; mulb'arts' 'mutter (about people)'; honărkos' 'signal', 'inform'; tasalkos' 'discuss', 'confer with'; tedosumbăs' 'squabble with'; Balebt'os' 'bumble', 'beg for mercy'.

(10) Такы лауг ниня, сидя вэнеку мадармончи', ты" турумонту.

taki lang n'in'a s'id'a ßen'eku
that slope on (something/somebody) two dog
madar-mon-čcif ti-? turu-mon-tu
bark-AUD-2.DU reindeer-PL grunt-AUD-3.PL

'On that slope two dogs are heard barking, reindeer are heard grunting.'

(Labanauskas 2001, 71)

Enets: mazud' 'bark (about a dog, fox, polar fox)'; d'or'id' 'speak', 'talk'; leud' 'shout', 'make noise'; p'is'id' 'laugh'.

(11) Пэхон бунэк мазумуноза.

pe-hon bunek mazu-muno-za

street-LOC dog bark-AUD-3.SG

'The dog is heard barking outside.'

(Tereschenko 1973, 145)

2. Multidirectional movement.

Nganasan: hezitisi 'go', 'walk', 'move'.

(12) Өаукутуомъны hедымыныч'е ууарата.

saykutuo-məni heói-mini-č́e yua-ra-ta

heavy-PROL go-AUD-3.SG door-AUGM-EL

'[Someone] is heard walking in a heavy manner near the door.'

(Porotova et al. 1981, 169) 
Nenets: jadesumbăs' 'walk', 'promenade'; m'inz' 'go', 'move', 'travel'.

(13) пихи-пихиня ядэсумбвондо'.

p'ih'i-p'ih'in'a jadesu-mb-ßon-dof

outside walk-DUR-AUD-3.PL

'Outside [the people] are heard walking.'

(Tereschenko 1990, 275)

Enets: d'azus' 'go', 'walk', 'move'.

(14) Менси отэ, тукада нообира. Обу дёдигон пехон дязда дязуунуза.

m'ens'i ote- $\emptyset-\emptyset$ tuka-da

old.woman wait-IND.PRAES-3.SG.S axe-POSS.3.SG

noob'ira- $\emptyset-\emptyset$ obu d'od'igon p'e-hon d'az-da d'azu-unu-za

hold-IND.PRAES-3.SG.S suddenly street-LOC go.on.foot-PTPRAES walk-AUD-3.SG

'An old woman is waiting, an axe is holding. Suddenly, outside someone going on foot is heard walking.'

(Sorokina \& Bolina 2005)

3. Being busy with something (work, entertainment, outward manifestation of one's feelings).

Nenets: p'indăs' 'store up wood for craftwork'; tinz' 'catch reindeer with a lariat'; jaygtăs' 'detach', 'take to pieces', 'ungum'; hinoc' 'sing (Nenets songs)'; hinamzas' 'lament'; lihirc' 'laugh spitefully, viperously'; jarc' 'weep'.

(15) Пихиня тымононту.

p'ih'in'a ti-monon-tu

outside catch.reindeer.with.lariat-AUD-3.PL

'Outside they are heard catching the reindeer with a lariat.' (Labanauskas 2001, 47)

Selkup: pac'itiqo 'chop firewood'.

(16) Pacitikun'ä.

paciti-kun'-ä

chop.firewood-AUD-3.SG.S

' $[\mathrm{He}]$ is heard chopping firewood.'

(Cheremisina \& Martynova 1991, 14)

B. Processes that reach an endpoint in the sphere of the subject of the action.

1. Processes with resultative semantics which also denote the communication of information. 
Nganasan: munsa 'say'.

(17) Мунумунучё: "Та̄че кәрытә"."

munu-munu-ču tā-če kərito- $\emptyset-$ -

say-AUD-3.SG reindeer[-PL]-POss.2.PL flog.along-IMP-2.SG.S

'He is heard saying, "Flog along your reindeer."'

(Tereschenko 1973, 46)

Nenets: manz' 'say', 'utter'; t'ores' 'give a shout', 'cry out'; manz' hanac' 'take the word'; mulămz' 'say something indistinctly in a foreign language'.

(18) Тарем' маманонда: "Тедхава' ханава"."

tar'emf ma-manon-da t'ed-haßaf hana- $\emptyset-\beta a ?$

so say-AUD-3.SG now-that's it die-IND.PRAES-1.PL.S

'[He] is heard saying so, "That's it now we are dying."' (Tereschenko 1990, 290)

Enets: mad' 'to say'; mad' kadas' 'to take the word'.

(19) Пэбу тазобэ ниохода мамунуза: "Тоди ани каней!"

pebu tazobe n'ioho-da mam-unu-za tod'i

junior shaman child-POSs.3.SG say-AUD-3.SG then

an'i kan'e- Ø-j

again set.off-IMP-2.SG.S

'Then a junior shaman is heard saying to his child, "Set off again!"'

(Labanauskas 2002, 117)

Selkup: čitiku 'say'.

(20) Куты кос нильчик читыкунæ.

kuti kos n'il'č́ik čiti-kunn'-æ

someone so say-AUD-3.SG.S

'Someone is heard saying so.'

(Tereschenko 1973, 146)

2. Movement of a resultative nature with the semantics of achieving the aim in space.

Nganasan: tujs'a 'come', 'arrive'; b'ujud'a 'leave', 'depart', 'set off', 'go to a place'.

(21) Сылычекӱӧ тӱймунучё.

siličček'ujo t'uj-munu-ču

someone come-AUD-3.SG

'Someone is heard coming.'

(ibid., 146) 
Nenets: tos' 'come', 'arrive'; hes' 'leave', 'depart', 'set off', 'go to a place'; teßăs' 'get to a place', 'reach'; tărpăs' 'come out'; s'id'ic' 'take a stroll on either side of something'.

(22) Сэр' я' тэта, пихи-пихиня тет хыедана тыд тованондо'.

serf jaf teta p'ih'i-p'ih'in'a t'et

Ser Ja Teta outside four

hijedana ti-d to-ßanon-dof

reddish-grayish reindeer-POSS.2.SG come-AUD-3.PL

'Ser Ja Teta, four reddish-grayish reindeer are heard coming outside.'

(ibid., 61)

Selkup: t'ugu 'come (to)'; šêrqo 'enter'.

(23) Ма̊тты тӱкунны.

måt-ti t'u-kunn-i

tent-ALL come-AUD-3.SG.S

'He is heard coming to the tent.'

(ibid., 146)

3. Actions of a resultative nature with the semantics of reaching a change in the subject's position in space (by means of that very action).

Nenets: sanas' 'jump', 'spring to one's feet'.

(24) Пухуча минханта санавонта.

puhuč́a m'inhanta sana-ßon-ta

old.woman immediately spring.to.feet-AUD-3.SG

'The old woman is heard springing to her feet [from her bed] immediately.'

(Labanauskas 2001, 27)

4. Other reflexive action verbs of a resultative character.

Nenets: p'odas' 'fight'; perc' 'treat somebody somehow'; sudabtas' 'shudder'; tajdos' 'crack all over'; p'ehedărc' 'open widely and quickly (e.g., about a door)'.

(25) Тыбканда ня' уавка хабтеуг нобт' пёдвонди'.

tibkan-da n'af yaßka habt'eng

axe-POss.3.SG with (somebody) tame.reindeer stag

nobtf p'od-ßon-d'if

together fight-AUD-3.DU

'My tame reindeer stag does not want to die'; lit., 'His axe together with the tame reindeer-stag is-heard-fighting.'

(Tereschenko 1990, 237) 
II. Actions directed to the object with the semantics of reaching the result of a purposeful action.

Nenets: manzaptas' 'touch something'; hos' 'find (out)', 'seek (out)'; taparpăs' 'kick', 'spur'; hadas' 'kill', n'a?mas' 'grasp', 'catch', 'take'; mes' 'take', 'sieze something'; s'aras' 'fasten', tas' 'bring', 'drag', 'drive (home)'; t'ul'es' 'carry in', 'bring in', 'drag in', 'pull in'.

(26) Тасий хадахабина" ям' ховонду'.

tasij hadahab'ina-? ja-mf ho-ßon-duf

down anchor-PL ground-ACC find-AUD-3.PL

'Under the water the anchors are heard finding the ground.' (Tereschenko 1990, 290)

Selkup: m'iqo 'give'.

(27) jjamDy nimasä na mikunyty.

ija-m-Di n'ima-s'ä na m'i-kuni-ti

son-ACC.SG-POSS.3.SG breast-INSTR.SG-ABS here give-AUD-3.SG.O

'Here [the mother] is-heard-giving her breast to her son.'

(Kazakevich 2009)

In the Samoyedic languages, Auditive affixes can also combine with nonactive verbs. There are two kinds of non-activity: (1) non-activity in that the subject does not act at all, yet energy necessary for fulfilling the action is exerted by the subject; and (2) non-activity related to the notion of passivity/patience (Avilova 1976, 112). When the Auditive is combined with non-active verbs, it indicates that the perceiving subject only fixes in the mind the presence of the sound he/she hears or some other general sense. The exact kind of perception of this 'general sense' meaning is only determined contextually; these can be both feelings about one's own state and feelings about the state of the environment.

Auditive forms are used with non-active dynamic verbs that denote:

1. Perception by sense-organs (by hearing and smell).

Nganasan: sojbusa 'be heard'; neluajsya 'be tasty'.

(28) Коч'уУӧгӧну поней д'амоðу өойбомуна?

kočuujogönu yonej d'amo-סu sojbo-muna-?

after.time again voice-POSS.3.SG be.heard-AUD-3.SG.R

'After a time again her voice is heard being heard.'

(Porotova 1980, 37)

(29) Матәну хихиә колы нелуаймӥнӱчё.

ma-tenu h'ih'iə koli n'eluaj-m'un'u-č́u

tent-LOC cooked fish be.tasty-AUD-3.SG

'[I] feel that the cooked fish in their tent is tasty.'

(Tereschenko 1979, 221)

Acta Linguistica Hungarica 62, 2015 
Nenets: yabt'es' 'smell', 'be odorous'; sos' 'be heard', 'feel', 'sense'.

(30) Вэсаков, сеуга мун" совононту!

ßesakov s'enga mun-? so-ßonon-tu

old.man bell-PL sound-PL be.heard-AUD-3.PL

'Old man, the sounds of the bell are heard being heard!'

(Labanauskas 2001, 26)

(31) Мато' пиревы халяхӑна уабтевонда.

ma-tof p'ireßi hal'a-hăna yabt'e-ßon-da

tent-GEN cooked fish-LOC smell-AUD-3.SG

'[I] sense-the-smell of cooked fish of their tent.'

(Tereschenko 1973, 145)

Enets: sos' 'be heard'.

(32) Обу дёдигон накую мякоз лэу соунуза.

obu d'od'igon nakuju m'a-koz leu so-unu-za

what during other tent-EL cry be.heard-AUD-3.SG

'After a time a cry is heard being heard from the other tent.'(Sorokina \& Bolina 2005)

2. Physical and psychological state of the subject. In this case the speaker is either the subject or the object of some action(s) performed with respect to him/her. If the speaker appears to be the object, he/she feels the result of the action(s) physically, i.e., 'on his/her own back'.

Nganasan: d'ilaridi 'be lifted'; kəmərusa 'be caught'; huarəd'erusa 'be struck', 'be hit'.

(33) Макизәнә ма̄гӱӧтәну хуарәдерумунӥнә.

mak'izənə māg'ujo-tənu huarəd'eru-mun'u-nə

behind something-LOC be.hit-AUD-1.SG

'I feel being hit with something from behind.'

(Tereschenko 1979, 221)

Nenets: hon'os' 'leep'; hănz'es' 'calm down', 'quiet down', 'settle down'; medărkas' 'limp slightly'.

(34) Тарем' инзеле: мякана хибяри" хонёвондо'.

tar'emf inz'el'e- $\emptyset-\emptyset$ m'a-kana h'ib'ar'i-? hon'o-ßon-dof

then listen-IND.PRAES-3.SG.S tent-LOC sleep-AUD-3.PL man-PL

'Then he listens: the people are heard sleeping in the tent.' (Tereschenko 1956, 250)

3. Constant change of the subject's state (a feature in the making/featureless change of the state of the subject).

Nenets: se?nas'alămz' 'become very quiet, noiseless'; s'id'os' 'wake up'; Benǒlas' 'get scared (about an animal)'. 
(35) Мякы мякана хибяри" сидёвондо', мякад пин(') топорнга".

m’aki m'a-kana h'ib'ar'i-? s'id'o-ßon-dof

domestic (relating to a tent) tent-LOC man-PL wake.up-AUD-3.PL

m'a-kad p'i-n(f) topor-nga- Ø-?

tent-EL street-LOC come.out-GRAD-IND.PRAES-3.PL.S

'The people are heard waking up in the tent, they are coming out into the street.' (ibid., 250)

Selkup: šiteiqo 'wake up'.

(36) Omyty na šiteikunä...

əmi-ti na šit-عi-kun-ä

mother-POss.3.SG here wake.up-INTEN/PERF-AUD-3.SG.S

'His mother here is-heard-waking up...'

(Kazakevich 2009)

4. A state of the subject that does not depend on this subject.

Nganasan: d'ar'is'i 'be sick', 'be sore'.

(37) Дӥтӱмә дяриминічи.

d'ut'u-mə d'ar'i-mini-č́i

hand-Poss.1.sG be.sore-AUD-3.SG

'My hand feels sore.'; lit., 'My hand [I] feel-be-sore.'

(Tereschenko 1979, 221)

5. Processes happening beyond the subject.

Nganasan: sorud'a 'rain'.

(38) Бәнтіәзу сорумунучй.

bənt'iəzu soru-munu-č́u

from.outside rain-AUD-3.SG

'[I] hear [it] is raining outside.'

(idem.)

6. Processes related with making sounds. The peculiarity of this group of verbs, which denote sound processes of inanimate nature and artifacts, is that there is no direct connection between the action and a specific subjectsource. This implies that there could potentially be many subject-sources for one type of sound.

(39) Nenets

Ханюй пя' мал маркадавонда.

han'uj p'a-f mal markada-ßon-da

frozen tree-GEN top break.with.crack-AUD-3.SG

'A frozen top of a tree is heard breaking with a crack.'

(Tereschenko 2003, 236)

Acta Linguistica Hungarica 62, 2015 
(40) Лэркабт' ханда маркадавонда.

lerkabtf han-da markada- $\beta$ on-da

suddenly sledge-POSS.3.SG break.with.crack-AUD-3.SG

'Suddenly his sledge is heard breaking with a crack.' (Kuprijanova et al. 1985, 219)

Nenets: sejnas' 'ring'; tebkădăs' '(re)sound', 'reach one's ears'; markadăs' 'break with a crash (all of a sudden and easily)'; mal'jos' 'cleave with a crash'; pendăs' 'burst (about a bubble)', 'ring out (about a shot)', 'go off (about a gun), etc.'; tokădărc' 'knock', 'tap on', 'patter on', 'rap'; tikadas' 'give a crack', 'give a crackle', 'resound'; munoc' 'make noise', 'resound', 'roar'; hurtsas' 'make noise'; yal'tsedărts' 'ring out (about shorts)'.

(41) Хой' яд' нид лохорта и" муно"монда.

hoj-f jad-f n'id lohor-ta i? muno?-mon-da

backbone-GEN slope-GEN from.above flow.fast-PTPRAES water roar-AUD-3.SG

'The water flowing fast from above the ridge of a slope is heard roaring.'

(Tereschenko 1973, 145)

The Auditive can be used with the following groups of non-active static verbs:

1. Verbs of existence.

Nganasan: is'a 'be', 'exist'.

(42) Тъгата д'интид'и танд'а? а ?'имуна.

təgata d'int'i-d'i tand'a?a Pi-muna- $\emptyset$

then heard-VAINF pregnant be-AUD-3.SG.S

'Then he heard that she is-perceived to be pregnant.'

(Porotova 1980, 25)

Nenets: jaygos' 'be absent', 'not to be', 'not to exist'; n'is' 'not to be (an auxiliary negative verb)'.

(43) Чуковами ненэчь нивонта уа".

č́ukoßam'i n'eneč n'i-ßon-ta ya-?

here human.being not-AUD-3.SG be-CONNEG

'One can feel it is not a human being.'

(Labanauskas 2001, 126)

Enets: es' 'be', 'exist'.

(44) Чики парнэр дёрируза эунуза.

čik'i parner d'or'i-ru-za e-unu-za

this witch talk-ONLY-POSS.3.SG be-AUD-POSS.3.SG

'Only the talk of this witch is perceived to exist.'

(Sorokina \& Bolina 2005) 
2. Verbs denoting the position of the subject/object in space. Sentences containing such verbs marked by the Auditive affix predicate the position of a particular perceived subject/object in some place that is within the range of the observer's perception.

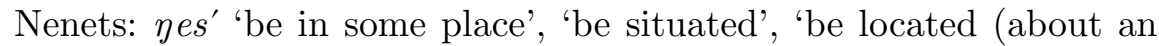
object)'; yamd'os' 'sit', 'stand', 'be in some place'; mes' 'be in some place (about a human being or an animal)'.

(45) Тикы яхана нисява" вэсако сијгы хан' ниня таня уамдёвонда.

t'iki jahana n'is'a- $\beta$ a? $\quad$ Besako s'ingi

at.this.time father-POSS.1.PL old.man behind.tent

han-f n'in'a tan'a yamd'o-ßon-da

sledge-GEN on still sit-AUD-3.SG

'At this time our father [who is an] old man behind the tent is heard sitting on the sledge.'

(Tereschenko 1990, 123)

Enets: yas' 'be in some place'.

(46) Пино кобуэза сэса наунуза.

p'ino kobue-za sesa na-unu-za

at.night bark-POSS.3.SG rustle be.in.some.place-AUD-3.SG

'At night the rustle of the bark is heard to be in this place.'(Sorokina \& Bolina 2005)

3. Verbs of thinking.

Nganasan: yated'a 'expect'.

(47) Тъгата канагӧ буа мелыðаӨы коптуа уатамунуч'у нонд'итӓ ма:?.

təgata kanag'o bua m’elióa-si koptua

then some step make-VAINF girl

yata-munu-ču nond'i-t'ä mā?

expect-AUD-3.SG stand-PTPRAES tent

'Then having made some steps, the girl is expecting by intuition a standing tent.'

(Porotova 1980, 27)

4. Verbs describing the characteristics of the subject.

Nenets: tosakăbt'os' 'be suspecious'; hurckabtas' 'be noisy disturbing others'; yadart'os' 'be loud'; yad'imz' 'appear'; 'become visible', 'become apparent', 'happen', 'occur'.

(48) Тюку мал' уани' тосакабтвонда сей' ябтадаб".

t'uku malf yan'if tosakabt-ßon-da s'ejf jabtada-b?

this all again be.suspicious-AUD-3.SG heart be.narrow-VACOND

'All this is felt to be suspicious [if] the heart is narrow (= fearful).'

(Tereschenko 1990, 45) 


\subsubsection{Semantic characteristics of the core types of predicates marked by the Auditive}

The above-suggested classification of the different semantic types of predicates makes it possible to accurately track the cases when Auditive affixes combine with predicates belonging to particular semantic classes. The most typical cases - those registered in all Northern Samoyedic languages - form the nucleus of the usages, whereas the others build up the periphery. It should also be stressed that the presence or absence of examples in Selkup does not play an important role in determining the semantic nucleus and periphery, as these forms are considered archaic. In this work, the Selkup examples have been provided only to demonstrate a complete picture of the Auditive usage.

The nucleus comprises cases when the Auditive marks the following semantic classes of predicates:

I. Active verbs denoting actions closed in the sphere of the subject.

A. Non-terminative action verbs with the semantics of (1) sounding and speaking, and (2) multidirectional movement.

B. Processes reaching their endpoints in the sphere of the subject of the action. These are processes of a resultative character with the semantics of communicating information.

The main component of situations described by active verbs of 'sounding and speaking' and 'communicating information' is a 'sound'. Consequently, situations described by these verbs are perceived by hearing. Like movement in general, the meaning of verbs of multidirectional movement contains no indication of a 'sound'. However, situations described by these active verbs suggest that the subject/object changes the position in space and that the change is normally accompanied by specific sounds. Information about these sounds constitutes the encyclopedic knowledge of the perceiving subject.

II. Non-active verbs.

A. Dynamic verbs denoting perception by sense-organs.

In the vast majority of cases that fall under this category the Auditive forms signal perception through hearing. Rare examples that include perception by smell have been recorded only in Nenets and Nganasan. The relation between perception by hearing and perception by smell appears to be natural. It also seems to be quite possible that the meaning 'perceive by a specific sense-organ, more particularly by hearing and by smell' has 
evolved from the meaning 'general sense irrelative of sense-organs'. Similar situations exist in other languages, for example, in the Slavic languages, words with the root $*_{c^{\prime}} u-: \check{c}^{\prime} u t^{\prime}$, $\check{c}^{\prime} u j a t^{\prime}$ ' have developed the meaning of 'perception by hearing and smell' from the meaning 'general sense irrelative of sense-organs' (Preobrazhenskij 1951, 83).

Both kinds of perception - hearing and smell - belong to a distant type since information from the perceived object arrives at each corresponding organ indirectly. There is no kind of physical contact between the perceiving subject and the perceived object: the only thing the perceived object does is 'sending' information about itself to the perceiving subject.

Distant types of non-visual perception (hearing and smell) are opposed to contact types (gustatory and olfactory). Despite the fact that some scholars suggest that the Auditive is used to denote perception by taste and touch in Northern Samoyedic languages, we have not encountered such examples.

B. Static verbs of existence.

Sentences containing verbs of this semantic class are existential-i.e., they predicate existence of a perceived object in a definite place. The place where the existence is conceived is identified broadly - as the whole world - whereas the implied place is determined by the context. As a rule, it is the place and the time where perception is happening, more exactly, in the perceptual space of the observer. If an existential sentence contains a negative verb, then what actually is negated is the existence of a perceived object in a definite place, but never existence in general. Negating the existence in a definite place does not contradict existence in a big place, which is the world.

Since the general meaning of existence is quite ephemeral, existence acquires a specific meaning only in particular contexts. The semantics of the Auditive in this case is very vague and, normally, is realized in the meaning of 'general sense' that becomes further specified as the context requires. These meanings include 'observe', 'note', 'recognize by sensing', and 'perceive by a particular sense-organ', as well as 'know', which means 'feel internally, conceive something often with the help of the sixth feeling, by heartfelt intuition'. This internal support or 'gut feeling' appears to be consciously available feedback from non-conscious and uncontrollable cognitive processes as in cases of surprise, revelation, etc. One's gut feelings presuppose the existence of a direct first-hand information source and, thus, are considered to be the non-visual experience or, in other words, experiential knowledge. Consider the semantics of the static verbs of existence in examples (42), (43), (44), repeated here: 
(42) Nganasan

Тъгата д'интид'и танд'а? а ?'имуна.

təgata d'int'i-d'i tand'a?a Pi-muna- $\emptyset$

then hear-VAINF pregnant be-AUD-3.SG.S

'Then he heard that she is perceived to be pregnant.'

(Porotova 1980, 25)

The meaning of the verb $i s^{\prime} a$ 'be/exist' is 'according to somebody's observation'.

(43) Nenets

Чуковами ненэчь нивонта уа".

čukoßam'i n'eneč $\quad$ n'i-ßon-ta ya-?

here human.being not-AUD-3.SG be-CONNEG

'One can feel it is not a human being.'

(Labanauskas 2001, 126)

The meaning of the negative verb $n$ 'is' 'not to be/exist' marked by the Auditive suffix is a 'gut feeling'.

(44) Enets

Чики парнэр дёрируза эунуза.

čik'i parner d'or'i-ru-za e-unu-za

this witch talk-ONLY-POSS.3.SG be-AUD-POSS.3.SG

'Only the talk of this witch is perceived to exist.'

(Sorokina \& Bolina 2005)

The meaning of the verb $e s^{\prime}$ 'be/exist' is 'perceive by a specific sense-organ, in particular, by hearing'.

\subsection{The renarrative semantics of the Auditive in the Nenets language}

Unlike Nganasan and Enets, in Nenets the paradigmatic meaning of the Auditive - reality - is complicated not only by the meaning of non-visuality but also by an indirect evidential meaning of renarrativity. The renarrative meaning of the Auditive is only realized in declarative sentences, and manifests itself when the Auditive marks non-active static predicates of the following semantics:

1. Verbs of existence: tăn'as' 'be (present)', 'be available'; n'is' 'not to be (an auxiliary negative verb)'; $i l^{\prime} s^{\prime}$ 'live'. 
(49) Чикы саля ниня няхар" Неняук тэта" илевонту.
čiki sal'a
n'in'a
n'ahar?

that peninsular on (something/somebody) three

n'en'ank teta-? il'e-ßon-tu

Nenyayk rich.reindeer-herder-PL live-AUD-3.PL

'Three rich reindeer-herders are said to live on that peninsular.

(Labanauskas 2001, 40)

2. Verbs of possession and belonging: tăn'as' 'have', 'possess'.

(50) Сядотаку не нюду танявонту пэсьты".

s'adotaku n'e n'udu tan'a- $\beta$ on-tu ne- $\emptyset-s^{\prime}=$ ti?

beautiful woman child have-AUD-3.SG be-3.SG.S-IND.PAST $=$ PRTCL

'They are said to have had a beautiful daughter.'

(ibid., 38)

3. Modal verbs: mes' 'intend', 'be going to do something'.

(51) Мале нядана" хэванзь мэвонда".

mal'e n'adana? heßa-n-z' me-ßon-da?

already from.us departure-n-VAINF intend-AUD-POSS.2.PL

'You are said to be going to leave us already.'

(Tereschenko 1973, 145)

According to our observations, the Auditive on very rare occasions combines with non-active dynamic and active verbs, whose semantics indicates that the energy needed for fulfilling the action is exerted by the subject.

(52) Ю” Нохор няна" я' нимня сахамондо'.

ju? nohor n'ana? ja-f n'imn'a saha-mon-dof

ten Noho very (much) land-GEN to be.in.bellicose.mood-AUD-3.SG

'Ten Naho are said to be in bellicose mood very much about our land.'

(Tereschenko 2003, 538)

In this example, the predicate is expressed by a non-active dynamic verb sahămz' 'be in bellicose mood, throw off reserve' denoting a psychological state of the subject.

In the semantic domain of perception, non-visual forms (evolving transferred meanings) expressing non-purposefulness realize the model: the meaning 'sensory perception' ('perceive by hearing') $\rightarrow$ epistemic meaning ('perceive/apprehend hearsay', 'know from hearsay'). 'Perception by hearing' and 'information acquired from someone else's report' are, in fact, two different ways of dealing with the same situation of 'obtaining information'. It is noteworthy that 'perception by hearing' is designated in the 'cycle of 
communication' model as being secondary relative to speaking: one can hear only what has been articulated by the other person. The auditory information is thus perceived as acquiring and processing information from someone else.

Replacement of the meaning 'perception by hearing' with 'indirect knowledge obtained by the speaker from someone else' becomes possible due to a common (for both kinds of knowledge) quality of perception: passive perception of the information, which implies that a corresponding sense-organ has not been consciously and purposefully used. The fact of obtaining information by the perceiving subject, both by hearing and from hearsay, signals that the speaker moulds an image of the perceived event. This image serves as a basis for a subsequent development of the mental meaning 'have in mind', that is 'know, have information, be known'.

(53) Парка нянту не нюдя танявонта.

yarka n'antu n'e n'ud'a tan'a-ßon-ta

big from.them woman child have-AUD-3.SG

'The eldest from them is said to have a daughter.'

(Labanauskas 2001, 35)

In analyzing the Auditive component in the renarrative meaning, two factors seem to be essential: the information source and the speaker's attitude toward the content of someone else's utterance. Indication of the information source is included into a particular mission of the speaker. In all the examples we have at our disposal, the information source is made explicit with the help of lexical means and appears to be concrete and definite (the guarantor of the information is named directly).

(54) Са"лако ма" нив': "Няхар" я' таханяна, няхар" яв' тяханяна тет ю” солотой уэбте танявононда".

sa?la-ko ma- $\emptyset-? \quad$ n'i- $\beta$ f $\emptyset$ n'ahar?

fool-Dim say-IND.PRAES-3.SG.S not-INTERR-3.SG.S three

jaf tahan'ana n'ahar? jaß-f tahan'ana

land-GEN behind three sea-GEN behind

t'et ju? solotoj nebt'e tan'a-ßonon-da

four ten gold horse be (available)-AUD-3.SG

'Doesn't a little fool say, "Behind the three lands, behind the three seas there are forty gold horses (it is said)."'

(Kuprijanova et al. 1985, 219)

Renarrating someone else's utterance by means of non-active static predicates in the Auditive form can be stylistically neutral. When 'neutral' renarration occurs, the Auditive expresses an external objective modality of reality. Its function is to indicate the speaker's detachment from the con- 
tent of somebody else's utterance. The speaker demonstrates that he/she objectively recounts somebody else's report and does not presume to judge how this report corresponds to factuality. The sole aim of the speaker is to familiarize the interlocutor with some concrete fact.

(55) Нярава сейси мамбата масьню”: “Няби я' вэкана няхар” Яв' мал” тэта" танявондо'”.

n'arava sejs'i ma-mba-ta ma- $\emptyset-s^{\prime}=n^{\prime} u ?$

Nyarava Sejsi say-DUR-PTPRAES say-3.SG.S-IND.PAST $=$ PRTCL

n'ab'i ja-f veka-na n'ahar? jaßj mal?

other land-GEN stretch-PTPRAES three Yamal

teta-? tan'a-von-dof

rich.reindeer-herder-PL be (available)-AUD-POSS.3.SG

'Nyarava Sejsi says, "On the other end of the land, three rich reindeer-herders are said to be."

(Tereschenko 1990, 133)

The fact that the speaker has not witnessed the event but rather learnt about it indirectly from someone else attests that the speaker is not completely confident in the reliability of the reported fact.

(56) Фавна хунанда манда" тарем' маци": "Сэр" сюнде”э е" сей”мана ёндалаванонда. Невхы нисянда мэ"мы салмхэй уынм', уынм' пюванонда".

naßna hunanda manda-? tar'emf

earlier once.upon.time speaker-PL so

ma-t-s'i-? ser? s'und'e-?e

Say-GRAD-INTERR.PAST-3.PL.S white hornless.reindeer-AUG

je? s'ej?-mana

in.the.direction.of heart[-PL]-PROL

jonda-la-ßanon-da n'eßhi n'is'a-n-da

move.from.place.to.place-INCH-AUD-3.SG old father-DAT-POss.3.SG

me?mi salmhej njin-mf njin-mf p'u-ßanon-da

well-worn smooth bow-ACC bow-ACC look.for-AUD-3.SG

'Earlier the speakers said so, "He is said to start moving from place to place through the hearts in the direction of a white huge hornless reindeer. For his old father a well-worn smooth bow, he is said to look for a bow." $\quad$ (Tereschenko 1990, 162)

jondalc' 'start moving from place to place' is a non-active dynamic verb; $p^{\prime} u s^{\prime}$ 'look for, seek' is a terminative active verb denoting an action with such an outer endpoint which is problematic to reach.

In Nenets, the Auditive also expresses emotive modality and can be reinterpreted with either a positive or a negative connotation. In the first case, this is usually fame, reputation, general recognition, or popularity. 
(57) Тад Нярава сейси пули" танявонда, нэнэсяри уод" тяхари са"монда.

tad n'arava s'ejs'i yul'i? tan'a-ßon-da

then Nyarava Sejsi all be (available)-AUD-3.SG

nenes'a-r'i yod? t'ahar'i sa?-mon-da

truth-only also very be.strong-AUD-3.SG

'Then all Nyarava sejsi is said to be, indeed he is said to be very strong.'

(Tereschenko 1990, 129)

Doubts about reliability arise when the speaker deliberately disagrees with somebody else's report. The speaker assesses the renarrated information negatively so that while being renarrated, the information may be accompanied by various negative emotions: indignation, bewilderment, reproach, mockery, etc. Through the neutral meaning 'information which has become available for everybody', the Auditive may develop negative connotations of seamy rumors or ill-fame.

(58) Фолери сюдбя тарем' вавонда: “Сэр" яханани неро' вэбахарт нивонда вадюр”."

nol'er'i s'udb'a tar'emf ßa-ßon-da ser?

only.one giant so say-AUD-3.SG white

ja-hana-n'i n'ero-f Beba-hart

land-LOC-POss.1.SG purple.willow-GEN leaf-even

n'i-ßon-da vad'ur- $\emptyset-$ ?

not-AUD-3.SG grow-IND.PRAES-3.SG.R

'The only one giant is heard saying so, "In my white land even a single leaf of a purple willow is said not to grow.",

(ibid., 65)

\section{Semantic transposition as reflection of grammemes dynamics at a synchronic snapshot}

The semantics of the Auditive is not confined to its paradigmatic meaning. It is quite typical of the Auditive to undergo semantic transposition, which is defined in grammar as a metaphorical use of a word-form or a syntactical structure in the function of its counter-member in a paradigm set. In a morphological paradigm, transposition is always associated with the syntagmatic relations into which the word-form enters with other units of the same level while the paradigmatic relations totally exclude it (Kuznetsova 1994, 214; 1995, 248). Consequently, semantic transposition signals that the word-form aquires new semantic properties in syntagmatics. Also, transposition is often associated with neutralization of semantic oppositions, which is understood as synonymic coincidence of the meanings of 
forms belonging to different paradigms within one morphological category. Despite the fact that transposition is the syntagmatic phenomenon located on the periphery of the grammatical system there may occur the situation when the number of neutralization cases exceeds the number of relevance cases. This results in complete destruction of the previous opposition. On this ground it is widely thought that transposition plays a crucial role in reorganizing morphological paradigms (Kuznetsova 1995, 104, 248).

\subsection{The 'Auditive $\rightarrow$ Renarrative' transposition in Nganasan}

The paradigmatic meaning of the Renarrative is reality (external objective modality) and secondary statement of an action (communicative modality). The latter connects the Renarrative with indirect evidentiality. The Renarrative mood is realized in declarative sentences. "In these sentences the statement that exists in one of its variants, either as affirmation or negation, forms the narrative speech forms - description, judgment, inference - that are characterized by the absence of a volitional feature" (Shentsova 1998, 34). Renarrativity along with interrogativity and inducement represents the sphere of communicative modality, which is otherwise understood as the purpose of communication/intention of the speaker. In Nganasan, these meanings of communicative modality are expressed in verbal morphology with the help of special moods: inducement by the Imperative, interrogativity by the Interrogative, statement by both the Indicative and the Renarrative (Usenkova 2002).

The Auditive unites with the Renarrative in different modal meanings. In the context of external objective modality of reality, the Auditive in the Renarrative meaning expresses reality not in a narrow sense, i.e., as actuality, but rather in a broad sense. Both the Auditive and the Renarrative can only express communicative modality in declarative sentences. Unlike the Auditive, which shows that the reported information originally belongs to the speaker, the Renarrative denotes that the speaker obtained the reported information second-hand. When used in the Renarrative sense, the Auditive expresses the meaning of 'be known to the speaker, know (learn) from someone else, from hearsay'.

In the contexts of evidentiality, the semantic basis of the opposition between the Auditive and the Renarrative appears to be a syncretic epistemic meaning 'know' and 'source of information'. In Nganasan, the Auditive is opposed to the Renarrative by the feature 'information acquired through one's own hearing and through personal access to the situation' (the zone of direct evidentiality)/'information acquired from someone else 
and implying absence of personal access to the reported situation' (the zone of indirect evidentiality). When the Auditive is transposed into the functional sphere of the Renarrative, it marks the predicates of both active and non-active semantics. The Auditive also signals that the speaker declines all his/her responsibility for this statement.

(59) Ń̈̈ərüбütüə d'indəmtu? münarə manu degirminit'i? iśüə.

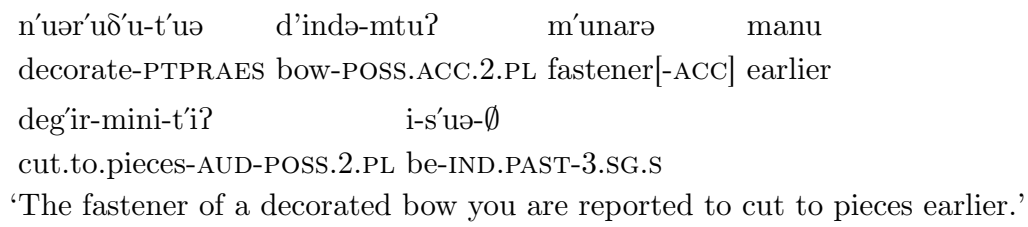

(60) Düsiri? ə́ ńuə təjmunə? ikətu Diəd'ə Bəঠətuə.

d'us'ir'i?ə n'uə təj-munə-?

Dyusirie[-GEN] son be (available)-AUD-3.SG.S

i-kə-tu- $\emptyset$ y'iəd'ə bəбətuə

be-ITER-IND.PRAES.CONT-3.SG.S Niede Bazatuo

'The son of Dyusirie is reported to be [known by name] Niede Bazatuo.' (idem.)

\subsection{The 'Auditive $\rightarrow$ Interrogative' transposition in Nganasan}

Rare cases of this kind of transposition have been registered only in Nganasan.

(61) Kunini hid'itiə hidini? Kunini hid'itiə sojbumunə?

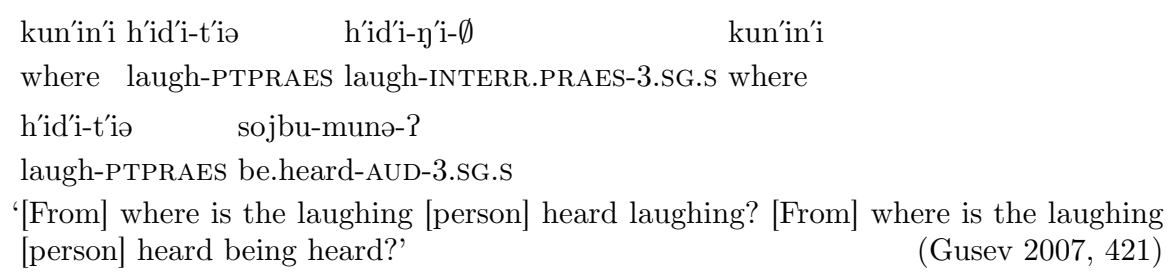

(Gusev 2007, 421)

The paradigmatic meaning of the Interrogative is a question about something unknown. The semantics of interrogativity is always complex. Besides expressing a question, it also includes the meaning of inducement: by asking a question, the speaker urges the addressee to react verbally. In the semantic sphere of the purpose of communication, the Auditive is opposed to the Interrogative by the feature of statement/question, but unites with it in the semantics of reality. Unlike the Interrogative, which 
expresses reality in a broad sense, reality expressed by the Auditive is reducible to actuality. Connection with communicating information draws the statement and interrogativity close together.

It appears, however, that an interrogative sentence containing a verb marked by the Auditive affix acquires a strong stylistic coloring. By using the Auditive verbal form, the speaker lets the listener know that the situation is definite, clear, and evident. At the same time, the Auditive accentuates that the speaker is not indifferent to an ongoing event; he/she is deliberately pretending that the situation is completely unknown to $\mathrm{him} /$ her and that it is the speaker's intention to make this situation clear. The transposed functioning of the Auditive forms in interrogative sentences seems to be quite common; for example, when playing 'hide and seek' with little children.

\subsection{The 'Approximative $\rightarrow$ Auditive' transposition in Enets and Nenets}

Perception can be realized in different spheres - sensory, intellectual, and irreal. In Nenets and Enets, the meaning of perception can be implied by a special non-evidential mood known in Samoyedology under different names including "the Comparative" (Boller 1857, 262), "vtoroye predpolozhiteljnoye naklonenie" ("the Second Suppositional Mood") (Verbov 1973, 99; Labanauskas 2002, 56), "naklonenie kazhushchegosya dejstviya" ("the Mood of a Seeming Action") (Labanauskas 1982, 283), "the Approximative" (Salminen 1998b, 530), and associated with the expression of irreal comparison.

The transposed use of the Approximative in the functional sphere of the Auditive is quite common in these languages. In particular, in Enets this fact was noted by Sorokina and Bolina, who wrote that "the markers -raha-/-rka-/-laha- are comparative-(as)similative, limitative-(as)similative, but sometimes they can express the meaning of the Auditive" (Sorokina \& Bolina 2005).

The semantic basis of the 'Approximative $\rightarrow$ Auditive' transposition is direct perceptual information about the situation to which the speaker has direct access. The examples we have at our disposal show that the Approximative can be used instead of the Auditive in the meaning of acquiring information through hearing only when it marks the predicates of active semantics. These are actions closed in the sphere of the subject: sounding and speaking. Verbs of this group contain a common semantic component - 'a sound' - and are naturally associated with perception by hearing. 
Nenets: lahanas' 'speak', 'talk'; sambădorts' 'speak with the soul of a deceased person'.

(62) Хонёбата уод" еваку уачекы пи ямпхана тургус сёвна пили" самбадоруа, самбадортараха.

hon'o-ba-ta yod? eßa-ku yačeki

sleep-DUR-PTPRAES also orphan-DIM child

p'i jamphana tungus s'o- $\beta$ na p'il'i?

night during Tungus throat-PRoL constantly

sambadorya- $\emptyset-\emptyset$

speak.with.soul.of.deceased.person-IND.PRAES-3.SG.S

sambador-ta-raha- $\emptyset$

speak.with.soul.of.deceased.person-PRAES-APPROX-3.SG.S

'During night, also [when] sleeping, the orphan is constantly speaking in the Tungus language with the soul of a deceased person, he is heard as if speaking with the soul of a deceased person.'

(Labanauskas 2001, 67)

Enets: d'or'id' 'speak', 'talk'; leud' 'shout', 'make noise'; p'is'id' 'laugh'.

(63) Онсехода, сеха дёридарха.

ons'ehoda s'eha d'or'i-da-rha- $\emptyset$

indeed somebody talk-PRAES-APPROX-3.SG.S

'Indeed, somebody is heard as if talking.'

(Sorokina \& Bolina 2005)

In its paradigmatic meaning, the Approximative expresses external objective modality of irreality, that is, the action is suppositional from the point of view of the speaker and is dependent on some conditions, causes, and situations. This mood is used in declarative sentences of irreal comparison.

(64) Nenets

Мэдаркана не тарцяри вадарим' уатевэкораха, пин' ти тибтидей”.

medarkana n'e tarts'a-r'i ßada-r'i-my

slightly.limping woman such-only speech-only-ACC.SG

yat'eßeko- $\emptyset$-raha- $\emptyset$ p'i-nf t'i t'ibt'id'ej- $\emptyset$-?

wait-PRAES-APPROX-3.SG.S outside-DAT.SG here swiftly.run.out-IND.PRAES-3.SG.S

'A slightly limping woman as if [she] were only waiting for such words, here [she] swiftly runs outside.'

(Tereschenko 1990, 60)

(65) Enets

Ороуми мигуа удэзарха.

oroum'i m'igua ude-za-rha- $\emptyset$

leading.reindeer something hear-PRAES-APPROX-3.SG.S

'The leading reindeer as if [it] heard something.'

(Labanauskas 2002, 132)

Acta Linguistica Hungarica 62, 2015 
The comparative component of the Approximative expresses 'the impressions of a conscious and perceiving subject', that is, the meaning of 'seemingness' that could be determined as a subjective impression or a subjective perception (Semjonova 2004, 151). This meaning imparts a strong subjective character to the constructions of irreal comparison, favours the formation of 'uncertain reports', and facilitates transposition of the Approximative into the functional sphere of the Auditive.

(66) Nenets

Пареуода' ню хад' мандараха: "Енертакодана" нибтув' тут"?"
par'egoda-? n'u ha-df man-da-raha- $\emptyset$
tsar-GEN child ear-DAT say-PRAES-APPROX -3.SG.S
jen'erta-ko-dana? n'i-btu- $\beta$ f- $\emptyset \quad$ tut-?

rifleman-DIM-DEST.1.PL not-ATTEN-INTERR-3.SG.S come-CONNEG

'The son of the tsar is heard as if saying in the ear, "As a little rifleman doesn't he come for us?"'

(Tereschenko 1990, 226)

(67) Enets

С̧ехоо мадараха: "Ума, модь с̧ий ноо".

s'ehoo ma-da-raha- $\emptyset$ uma $\bmod ^{\prime}+\mathrm{s}^{\prime} \mathrm{ij}$ noo- $\emptyset-(?)$

someone say-PRAES-APPROX-3.SG.S mother I-ACC take out-IMP-2.SG.S

"Someone [from the ice-hole] is heard as if saying: "Mother, take me out [of water]."

(Sorokina \& Bolina 2005)

"Uncertainty of the speaker in the veracity of the situation is connected with the characteristic of sufficiency/insufficiency of the information. This feature reflects the quantitative assessment of the available information and the degree of its reliability" (Ioanesân 1993, 94). The Approximative describes events the probability of whose realization is very high. These are the situations that occur under conditions of a first-hand sensory perception, when the perceiving subject is in direct contact with the object under assessment. At the same time, these situations could be characterized by problematic reliability: impediments during perception cause insufficiency of the information for the observer (Beljaeva 1990, 165, 169). The 'impediments' may be connected with both functional and psychological states of the perceiving subject - hearing sensitivity, fatigue, and overexcitement - as well as with conditions in the environment such as, for instance, unwanted sounds, or distorted, unclear, and not quite loud acoustic signals. In the process of impeded perception, the speaker discerns the situation rather poorly. 
Thus, the Approximative used in the Auditive meaning focuses on the subjective impression of the perceiving subject and is caused by some auditory impediments during perception. At the same time, the use of the Approximative implies that the observer has direct access to the situation and personal access to the information source.

(68) Nenets

Юдерпананта уоб лаханана лахнанараха: "Еваку уачекы, чуку, яв вархана пон нён мы'".

juder-pa-na-nta yob lahana-na

see.prophetic.dreams-VACOND-na-POSS.3.SG one speaker-PTPRAES

lahna-na-raha- $\emptyset \quad$ jeßa-ku yačeki čuku

speak-PRAES-APPROX -3.SG.S orphan-DIM child that

jaß $\beta$ ar-hana pon n'o- $\emptyset$-n mi-?

sea shore-LOC for.long.time not-IND.PRAES-2.SG.S stay-CONNEG

'When he has been seeing prophetic dreams some spearker is heard as if speaking, "Orphan-child, do not stay for a long time on that sea shore!"'(Labanauskas 2001, 67)

(69) Enets

Обу дёдигон нэ эчи ноддархаза, кабе касаза нода дёридарха, мадараха нода: "Аба, эу съий из пуу."

obu d'od'igon ne eči nod-da-rha-za

what during woman young hear-PRAES-APPROX-3.SG.S

kab'e kasa-za noda d'or'i-da-rha- $\emptyset$

dead sister-POss.3.SG she[-ALL] speak-PRAES-APPROX-3.SG.S

ma-da-raha- $\emptyset$ noda aba eu

say-PRAES-APPROX-3.SG.S she[-ALL] elder.sister here

s'ij iz puu- $\emptyset-(3)$

I[-ACC] not[NEGATIVE PRTCL] put-IMP-2.SG.S

'All of a sudden it seems to the girl that she hears the dead sister as if heard speaking to her, as if heard saying to her, "Elder sister, do not put me here."

(Sorokina \& Bolina 2005)

When the Approximative is transposed into the functional sphere of the Auditive, the former always indicates an explicit and concrete source of information.

(70) Enets

Парнэ мадараха: "Онэй нэ, онэй нээ, торь с̧ит мус̧ь комазудь".

parne ma-da-raha- $\emptyset$ onej ne onej

witch say-PRAES-APPROX-3.SG.S genuine woman (an Enets woman) genuine 
nee tor' s'it mu-s' koma-zu-d'

woman in.this.way you[-ACC] capture-VAINF want-IND.PAST-1.SG.S

'The witch is heard as if saying: "An Enets woman, an Enets woman, in this way I wanted to capture you."'

(idem.)

\subsection{The 'Indicative $\rightarrow$ Auditive' transposition in the Samoyedic languages}

In all Samoyedic languages, the meaning of reality (especially, its factual nature) appears to also be the paradigmatic meaning of the Indicative. However, unlike the Auditive, which is specifically marked for direct evidentiality, the Indicative remains neutral regarding direct/indirect evidentiality. This means that in the opposition between the Auditive and the Indicative, the latter is an unmarked member. Due to its neutrality, the Indicative expresses reality in a broad sense, as consisting of a core (actuality) and a periphery that includes the following potential meanings: the future, possibility, necessity, desire, as well as reality complicated by the assessment of reliability (Bondarko 1990a, 73).

A common semantic zone of actuality builds up the basis for transposition of the Indicative into the functional sphere of the Auditive. Since the functional sphere of the Auditive is narrower than the corresponding sphere of the Indicative, transposition in the reverse direction - 'Auditive $\leftarrow$ Indicative' - is impossible.

(71) Nganasan

Фәнә"санә дямо сойбуту.

yənə?sanə d'amo sojbu-tu- $\emptyset$

human voice be.heard-IND.PRAES.CONT-3.SG.S

'The human voice is being heard.'

(Tereschenko 1979, 221)

(72) Ны та:ч'у тонуци? е матуд'ӓ.

ni tā-č́u tonu-l'i-?e- $\emptyset$ ma-tu-d'ä

woman reindeer[-PL]-POSS.3.SG drive-INCH-IND.PRAES.PERF-3.SG.S tent-POSS.3.SG-ALL

'The woman has driven her reindeer to her tent.'

(Porotova et al. 1981, 168)

(73) Nenets

Ибедолы": "Нгамгэ пихид сензи" мун" со"?"

ib'edo-li- $\emptyset$-? ngamge p'i-h'id s'enz'i-?

think-INCH-IND.PRAES-3.SG.S why outside-EL bell-PL

mun-? so- $\emptyset-?$

sound-PL be.heard-IND.PRAES-3.PL.S

'[An old woman] starts thinking, "Why are the sounds of bells heard outside?"'

Acta Linguistica Hungarica 62, 2015

(Tereschenko 1956, 251) 
(74) Тяхау льаукхана уымты, тайна тяльуа.

t'aha-n l'ank-hana nimti- $\emptyset-\emptyset$

river-GEN.SG bank-LOC sit-IND.PRAES-3.SG.S

tajna t'al'ya- $\emptyset-\emptyset$

there cry-IND.PRAES-3.SG.S

'[The brother] is sitting at the bank of the river, [he] is crying.'

(Koshkarjova et al. 2003, 77)

(75) Enets

Бунэк мазу суа.

bunek mazu sua- $\emptyset-\emptyset$

dog[-GEN] barking be.heard-IND.PRAES-3.SG.S

'The barking of a dog is heard.'

(Labanauskas 2002, 46)

(76) Дёа леууа, мана: "Ши ооте'."

d'oa leu-na- $\emptyset$ mana- $\emptyset-\emptyset \quad$ ši oot'e- $\emptyset-\emptyset$

Dyoa cry-IND.PAST-3.SG.S say-IND.PRAES-3.SG.S I[-ACC] wait-IMP-2.SG.S

'Dyoa cried, he says: "Wait for me."'

(Sorokina \& Bolina 2005)

(77) Selkup

поҮон тебы́с'кут л'анггын'ет.

pojuon t'ebis'kut l'anggi-n'-et

outside someone shout-IND.PRAES-3.PL.S

'Someone is shouting outside.'

(Porotova 1976, 49)

(78) Матkан амда, понен каида лук'ирна.

mat-kan amd- $\emptyset$-a pon'en kaida luk'ir-n-a

house-LOC(ABS) sit-IND.PRAES-3.SG.S outside something knock-IND.PRAES-3.SG.S

'[Itya] is sitting at home, something is knocking outside.'

(Porotova 1980, 70)

\section{The Auditive in Selkup}

The evolutionary process of the loss of Auditive forms from the norm and from the system of the Selkup language can be observed empirically. In the 1920s, the Auditive was obligatorily used in corresponding consituational conditions. However, by the 1970s, Auditive forms were retained in the language memory only by the elderly generation. At the end of the 1980 s, these forms were not recognized by native speakers. The loss of the Auditive from the language system resulted in a considerable rebuilding of the paradigm of the category of evidentiality (Iljina 2002, 17). 
At present the Selkup language has only one mood, the Latentive, which represents indirect evidentiality. The Latentive has a very comprehensive semantics. In addition to its primary meaning of inference, this mood can also express the renarrative and non-visual meanings. Some Samoyedologists observe that the Latentive is used in cases where Auditive forms used to be employed (Kuznetsova et al. 1980, 241).

(79) tünty (instead of tükünä).

t'u-nt-i t t'u-k'un'ä- $\emptyset$

come-LATENT.PRAES-3.SG.S come-AUD-3.SG.S

'He is heard coming.'

(ibid., 242)

\section{Conclusion}

In the Samoyedic languages evidentiality finds its expression in verbal morphology. The meanings of non-visuality are expressed by a special mood, traditionally termed the Auditive in Samoyedology. The present paper has intended to make a thorough description of this evidential mood taking into account the peculiarities of interaction between the categories of evidentiality and modality.

The paradigmatic meaning of the Auditive is reality, complicated by the meaning of non-visual perception. The Auditive expresses reality in a narrow sense as actuality, which manifests itself in the situation of the Actual Present - experienced, perceived, definite, and evident for the observer.

Regarding evidentiality, the Auditive expresses direct evidentiality, in particular, non-visual perception: in situations witnessed by an observer, perception provides direct-sensory orientation in the external world and becomes the reference point for a specific channel of information. Phenomenological knowledge, encoded by non-visual perception, can be characterized as untargeted, passive, and uncontrollable.

Non-visual perception is ontologically connected with the notional category of purpose; more specifically, with the realization of this category as the semantics of non-purposefulness. Within the limits of nonpurposefulness, the meaning of perception develops in increasing differentiation: from a general sense of perception irrespective of sense-organs, perception from the impressions of the states of the body, sensuous knowledge, and activity directed to self-cognition to specific kinds of perception by sense-organs, with the exception of visual perception. This makes it possible to regard non-purposefulness as a semantic basis that underlies 
the development of the category of non-visuality. The meanings of passivity and uncontrollability are organically interwoven with the semantics of non-purposefulness and find their continuations in the semantics of nonvisuality.

The present analysis has revealed that the Auditive expresses different non-visual meanings depending on the semantic type of the predicate with which it combines. It has been discovered that in all Northern Samoyedic languages the Auditive can be found with the following semantic groups of predicates:

I. Active verbs, denoting actions closed on the subject and perceived only by hearing.

A. Non-terminative verbs with the semantics of (1) sounding and speaking, and (2) multi-directional movement.

B. Processes, which reach their endpoints in the sphere of the subject of the action. These are processes of a resultative character with the semantics of communicating information.

II. Non-active verbs.

A. Dynamic verbs of perception by sense-organs. In the majority of these cases, Auditive forms signal perception by hearing. In Nenets and Nganasan, there have been also recorded the cases when the Auditive marks perception by smelling but these examples are few in number.

B. Static existential verbs. When Auditive affixes combine with the transient semantics of these verbs, the Auditive is realized in a somewhat vague meaning of general sense, which in turn undergoes further contextual specification.

In each language of the Samoyedic family, the Auditive substantially differs in size and semantics. In particular, it has been established that in Nenets the paradigmatic meaning of the Auditive also covers an indirect evidential meaning of renarrativity. In Nganasan and Enets, renarrativity is not included in the primary meaning of the Auditive, as these languages have special moods to express renarrativity: the Renarrative and the Reportive, correspondingly.

A grammatical category is a historically changing category. The principle of historicism advocated by diachronic typology puts forward, as its sine qua non condition, the idea of gradual development of language, a tool 
which serves the developing mind of a human. This principle inevitably leads to recognizing the historical character of lexical and grammatical categories. Thus, a grammatical category cannot be represented in a description as a static synchronic snapshot of oppositions on the plane, but only as a system existing in motion and development, in whole and in its discrete parts. To overcome the gap between synchrony and diachrony language phenomena should be approached processually.

The processual approach to the study of language requires that special attention should be paid to transitional cases, which reflect dynamics of language development in its present state. Therefore, in examining the behaviour of Auditive word-forms syntagmatically, the focus has been on peripheral cases in their transpositional use. Penetrating into the functional sphere of the other mood the Auditive appears to be tied to specific communicative sentence types. Only in these syntactical structures the Auditive acquires the meaning of the other mood. In this paper, the following transpositional possibilities involving participation of the Auditive have been discussed:

The 'Auditive $\rightarrow$ Renarrative' opposition in Nganasan is regarded to be strong, as the forms of these moods are differentiated with respect to their categorial meanings. The semantic basis of this transposition is external objective modality of reality. Confinement of these moods to declarative sentences when expressing the purpose of communication appears to be of high importance. The Auditive and the Renarrative are two different ways of treating the same situation: 'obtaining information'. The Auditive is opposed to the Renarrative by the feature of direct/indirect evidentiality. Transposition of the Auditive into the sphere of use of the Renarrative means first of all realization of the model 'the meaning of sensory perception' $\rightarrow$ 'perceive/apprehend hearsay', 'learn of something at second hand'.

The semantic foundation of the strong 'Auditive $\rightarrow$ Interrogative' opposition in Nganasan is external objective modality of reality and connection with communicating information. This opposition is not homogeneous as the Interrogative here reflects only communicative modality, whereas the Auditive expresses non-visual direct evidentiality. Transposed use of the Auditive into the functional sphere of the Interrogative contributes to the emergence of a specific stylistic effect.

The 'Approximative $\rightarrow$ Auditive' opposition in Enets and Nenets can be characterized as strong because the moods are opposed to each other in their categorial meanings by the feature of non-evidentiality/evidentiality. Regarding modality both moods express external objective modality, within the limits of which they are opposed by the feature of irreality/real- 
ity. The opposition between the Approximative and the Auditive is possible due to a common meaning of perception that underlies the semantics of both moods. Because it is the mood of direct evidentiality, the Auditive realizes the meaning of perception in the sensory sphere that exists for the observer as a situation of the highest degree of reality: actuality. The Approximative expresses the meaning of perception in the sphere of irreal comparison as 'seemingness' ('subjective impression'). This mood signals that information acquired by the speaker is direct and first-hand, but distorted because of some impediments in perception: visual, auditory, olfactory, etc. Transposed use of the Approximative into the functional sphere of the Auditive is connected with both specifying information source and attendant circumstances of obtaining information: the perceiving subject acquires first-hand information that turns out to be distorted due to impediments in hearing (Kuznetsova \& Usenkova 2014, 210-212).

The 'Indicative $\rightarrow$ Auditive' transposition. All the Samoyedic languages demonstrate the possibility of a transposed use of 'neutral' and 'semantically capacious' Indicative into the functional sphere of the Auditive. In spite of the fact that the primary modal meanings of the Auditive and the Indicative coincide - they both express external objective modality of reality - the Auditive can express only a part of this reality: actuality. The Auditive also expresses the meaning of non-visual direct evidentiality, for which reason the sphere of its use is narrower than the corresponding sphere of the Indicative.

\section{References}

Abondolo, Daniel (ed.). 1998. The Uralic languages. London \& New York: Routledge.

Aikhenvald, Alexandra Y. 2003. Mechanisms of change in areal diffusion: New morphology and language contact. Journal of Linguistics 39. 1-29.

Aikhenvald, Alexandra Y. 2004a. Evidentiality. Oxford: Oxford University Press.

Aikhenvald, Alexandra Y. 2004b. Evidentiality. Problems and challenges. In P. van Sterkenburg (ed.) Linguistics today - Facing a greater challenge. Amsterdam \& Philadelphia: John Benjamins. 1-29.

Aikhenvald, Alexandra Y. 2006. Evidentiality in grammar. In K. Brown (ed.) Encyclopedia of language and linguistics. Vol. 4. Oxford: Elsevier. 320-325.

Aikhenvald, Alexandra Y. and Robert M. W. Dixon. 2014. The grammar of knowledge: A cross-linguistic typology. Oxford: Oxford University Press.

Avilova, Natalja S. 1976. Vid zaloga i semantika glagoljnogo slova. Moscow: Nauka.

Beljaeva, Elena I. 1990. Dostovernostj. In Bondarko (1990b, 157-170). 
Boller, Anton. 1857. Die Übereinstimmung der Tempus- und Moduscharaktere in den uralaltaischen Sprachen. In Sitzungsberichte der Philosophisch-Historischen Classe der Kaiserlichen Akademie der Wissenschaften. XXII. Band. II. Heft. Jahrgang 1856, December. Wien: Akademie der Wissenschaften. 223-263.

Bondarko, Alexandr V. 1990a. Realjnostj/irrealjnostj i potentsialjnostj. In Bondarko (1990b, 72-79).

Bondarko, Alexandr V. (ed.). 1990b. Teorija funktsionaljnoj grammatiki. Temporaljnostj. Modaljnostj. Leningrad: Nauka.

Burkova, Svetlana I. 2004. Evidentsialjnostj i epistemičeskaja modaljnostj v nenetskom jazyke. In Y. A. Lander, V. A. Plungjan and A. Y. Urmančiev (eds.) Issledovaniya po teorii grammatiki 3. Irrealis i irrealjnostj. Moskva: Gnozis. 353-374.

Burkova, Svetlana I. 2010. Kratkij ocherk grammatiki tundrovogo dialekta neneckogo jazyka. In N. B. Koshkarjova (ed.) Dialektologicheskij slovarj neneckogo jazyka. Ekaterinburg: Basko. 180-349.

Cheremisina, Maja I. and E. I. Martynova. 1991. Seljkupskij glagol: formy i ih syntaksicheskije funktsii. Novosibirsk: Izdateljstvo NGU.

Collinder, Björn. 1957. Survey of the Uralic languages. Uppsala: Almquist \& Wiksells.

Comrie, Bernard. 1981. Language universals and linguistic typology: Syntax and morphology. Chicago: The University of Chicago Press.

De Haan, Ferdinand. 1998. The category of evidentiality. Manuscript. http://www.unm.edu/ fdehaan/catevid.txt (accessed in 2001)

De Haan, Ferdinand. 2008. Semantic distinctions of evidentiality. In M. Haspelmath, M. S. Dryer, D. Gil and B. Comrie (eds.) The world atlas of language structures online. Munich: Max Planck Digital Library. chapter 77. http://wals.info/feature/description/77 (accessed 17 July 2011)

Ermolaeva, Ljudmila S. 1987. Očerki po sopostaviteljnoj grammatike germanskih jazykov. Moskva: Vysšaya škola.

Gusev, Valentin Y. 2007. Evidentsialjnostj v nganasanskom jazyke. In Hrakovskij (2007, 415-444).

Haarmann, Harald. 1970. Die Indirekte Erlebnisform als grammatische Kategorie. Eine eurasische Isoglosse. Band 2. Wiesbaden: Otto Harrassowitz.

Helimski, Eugene A. 1994. Očerk morfonologii i slovoizmeniteljnoj morfologii nganasanskogo jazyka. In E. A. Helimski (ed.) Tajmyrskij etnolingvističeskij sbornik: Materialy po nganasanskomu šamanstvu i jazyku 1. Moskva: RGGU. 190-221.

Helimski, Eugene A. 1998a. Nganasan. In Abondolo (1998, 480-515).

Helimski, Eugene A. 1998b. Selkup. In Abondolo (1998, 548-579).

Helimski, Eugene A. 2001. Samoyedic studies: A state-of-the-art report. Finnisch-Ugrische Forschungen 56. 175-216.

Hrakovskij, Viktor S. (ed.). 2007. Evidentsialjnostj v jazykah Evropy i Azii. St. Petersburg: Nauka.

Iljina, Ljudmila A. 2002. Evoljutsija glagoljnoj kategorii evidentsialjnosti (sistemno-diahronicheskoje modelirovanije na materiale seljkupskogo jazyka). Doctoral dissertation. Novosibirsk.

Ioanesân, Evgenija R. 1993. Klassifikatsiya mentaljnyh predikatov po tipu vvodimyh imi suždenij. In N. D. Arutjunova (ed.) Logičeskij analiz jazyka. Mentaljnyje dejstvija. Moskva: Nauka. 89-95. 
Janhunen, Juha. 1998. Samoyedic. In Abondolo (1998, 457-479).

Kanakin, Igor A. 1996. Jazyki sosedej. Tjumenj: Institut problem osvojenija Severa SORAN.

Kazakevich, Olga A. 2009. K voprosu o soglasovanii kak sposobe oformlenija sintaksicheskoj svjazi v severnyh seljkupskih govorah. Manuscript. www.ksu.ru/conf/LENCA (accessed in March 2010).

Koshkarjova, Natalja B., Svetlana I. Burkova and Valentina V. Shilova. 2003. Expeditsionnyje materialy. Obraztsy textov na lesnom dialekte Nenetskogo jazyka. In N. N. Shirobokova and N. B. Koshkarjova (eds.) Jazyki korennyh narodov Sibiri. Vol. 7. Part 2. Novosibirsk: Izdateljstvo Novosibirskogo Gosudarstvennogo Universiteta, Institut Filologii SORAN.

Kravchenko, Alexandr V. 1996. Jazyk i vosprijatie: kognitivnyje aspekty jazykovoj kategorizatsii. Irkutsk: Izdateljstvo Irkutskogo Universiteta.

Kuprijanova, Zinaida N., Marija Y. Barmič and Ljudmila V. Homič. 1985. Nenetskij jazyk. Učebnoje posobije dlja pedučilišč. Leningrad: Prosveščenije.

Kuznetsova, Ariadna I., Eugene A. Helimski and Elena V. Grushkina. 1980. Ocherki po seljkupskomu jazyku. Vol. 1. Moscow: Izdateljstvo Moskovskogo Universiteta.

Kuznetsova, Nadežda G. 1994. K sistematizatsii javlenij transpozitsii v morfologičeskoj paradigme. Linguistica Uralica 30. 203-216.

Kuznetsova, Nadežda G. 1995. Grammatičeskije kategorii južno-seljkupskogo glagola. Tomsk: TGPU.

Kuznetsova, Nadežda G. and Eleonora V. Usenkova. 2004a. Aktseptiv v nenetskom jazyke. Gumanitarnyje nauki v Sibiri 4. Novosibirsk: Sibirskoje Otdelenije RAN, Izdateljstvo SO RAN.

Kuznetsova, Nadežda G. and Eleonora V. Usenkova. 2004b. Kategorija evidentsialjnosti v nganasanskom jazyke. Linguistica Uralica 1. 28-39.

Kuznetsova, Nadežda G. and Eleonora V. Usenkova. 2006. Inferentsial v nenetskom jazyke. Linguistica Uralica 42. 276-296.

Kuznetsova, Nadežda G. and Eleonora V. Usenkova. 2014. Comparative constructions of similarity in Northern Samoyedic languages. Acta Linguistica Hungarica 61. 177-223.

Künnap, Ago. 1978. System und Ursprung der Kamassischen Flexionssuffixe. II. Verbalflexion und Verbalnomina. Helsinki: Suomalais-Ugrilainen Seura.

Künnap, Ago. 2002. On the Enets evidential suffixes. Linguistica Uralica 2. 145-153.

Labanauskas, Kazimir I. 1981. Predpolozhiteljnoje naklonenije v nenetskom jazyke. Sovetskoje Finno-Ugrovedenije 1. 49-61.

Labanauskas, Kazimir I. 1982. Naklonenije kažuščegosja dejstviya. Sovetskoje Finno-Ugrovedenije 4. 283-292.

Labanauskas, Kazimir I. 1992. Folklor Narodov Tajmyra. Entsy. Vol. 1. Dudinka.

Labanauskas, Kazimir I. 2001. Skazy sedoj stariny. Nenetskaja foljklornaja hrestomatija. Moskva: Russkaja literatura.

Labanauskas, Kazimir I. 2002. Rodnoje slovo. St. Petersburg: Prosveščenije.

Ljublinskaja, Marina D. and Andrej L. Maljčukov. 2007. Evidentsialjnostj v nenetskom jazyke. In Hrakovskij (2007, 445-46).

Lytkin, Vasilij I. 1960. O edinoj nauchnoj transkriptsii zvukov finno-ugorskih jazykov. Moscow \& Leningrad: Institut jazykoznanija AN SSSR.

Acta Linguistica Hungarica 62, 2015 
Marcantonio, Angela. 2002. The Uralic language family. Facts, Myths and Linguistics. Oxford \& Malden, MA: Blackwell.

Matkhanova, Irina P. 2000. Vyskazyvanija s semantikoj sostojanija v sovremennom russkom jazyke. Novosibirsk: Izdateljstvo NGPU.

Mikola, Tibor. 1995. Morphologisches Wörterbuch des Enzischen (Studia Uralo-Altaica 36). Szeged: Universitas Szegediensis de Attila József Nominata.

Nikolaeva, Irina Alekseevna. 2014. A grammar of Tundra Nenets. Berlin \& New York: De Gruyter Mouton.

Perrot, Jean. 1996. Un médiatif ouralien: l'auditif en Samoyède Nenets. In Z. Guentchéva (ed.) L'énonciation médiatisée. Éditions Peeters: Paris. 157-168.

Pokorny, Julius. 1959. Indogermanisches Etymologisches Wörterbuch. Band I. Bern \& München: Franke Verlag.

Porotova, Tatjana I. 1976. Skazki narodov sibirskogo severa. Vol. 2. Tomsk: Izdateljstvo Tomskogo Universiteta.

Porotova, Tatjana I. 1980. Skazki narodov sibirskogo severa. Vol. 3. Tomsk: Izdateljstvo Tomskogo Universiteta.

Porotova, Tatjana I., Erika G. Bekker, R. S. Gajer, K. F. Gritsenko and R. F. Denning. 1981. Skazki narodov sibirskogo severa. Vol. 4. Tomsk: Izdateljstvo Tomskogo Universiteta.

Potebnja, Alexandr A. 1993. Myslj i jazyk. Kiev: SINTO.

Preobrazhenskij, Alexandr G. 1951. Etymological dictionary of the Russian language. New York: Columbia University Press.

Prokofjev, Georgij N. 1937. Nganasanskij (tavgijskij) dialect. In G. N. Prokofjev (ed.) Jazyki i pisjmennostj narodov Severa. Part 1: Jazyki i pisjmennostj samojedskih i finno-ugorskih jazykov. Moscow \& Leningrad: Nauka. 53-75.

Prokofjeva, Ekaterina D. 1966. Seljkupskij jazyk. In V. I. Lytkin, K. E. Majtinskaja, P. A. Ariste, M. N. Koljadenkov, B. A. Serebrennikov and N. M. Tereschenko (eds.) Jazyki narodov SSSR. Vol. 3. Finno-ugorskije i samodijskije jazyki. Moscow: Izdateljstvo Nauka. 396-416.

Salminen, Tapani. 1997. Tundra Nenets inflection. Helsinki: Suomalais-Ugrilainen Seura.

Salminen, Tapani. 1998a. A morphological dictionary of Tundra Nenets (lexica societatis fenno-ugricae 26), vol. 26. Helsinki: Suomalais-Ugrilainen Seura.

Salminen, Tapani. 1998b. Nenets. In Abondolo (1998, 516-547).

Semjonova, Tatjana I. 2004. Kontseptualizatsija emotsionaljnyh sostojanij čerez modus kažimosti. In: Germanistika v Rossii. Traditsii i perspectivy. Novosibirsk: Novosibirsk State University. 150-153.

Serebrennikov, Boris A. 1964. Osnovnyje linii razvitija padezhnoj i glagoljnoj system v uraljskih jazykah. Moscow: Nauka.

Shentsova, Irina V. 1998. Shorskij glagol. Funktsionaljno-semanticheskoje issledovanije. Habilitation thesis, Moscow.

Sorokina, Irina P. and Darja S. Bolina. 2005. Enetskije teksty. St. Petersburg: Nauka. http://iling.spb.ru/nord/materia/ency_tit.html (accessed 17 July 2011)

Tereschenko, Natalja M. 1956. Materialy i issledovanija po jazyku nentsev. Moscow \& Leningrad: AN SSSR. 
Tereschenko, Natalja M. 1973. Sintaksis samodijskih jazykov. Prostoje predlozhenije. Leningrad: Nauka.

Tereschenko, Natalja M. 1979. Nganasanskij jazyk. Leningrad: Nauka.

Tereschenko, Natalja M. 1990. Nenetskij epos: Materialy i issledovanija po samodijskim jazykam. Leningrad: Nauka.

Tereschenko, Natalja M. 2003. Nenetsko-russkij slovarj. St. Petersburg: Prosveshchenije.

Usenkova, Eleonora V. 2002. Renarrativ v nganasanskom jazyke. Linguistica Uralica 38. $50-58$.

Vende, Kullo. 1967. Finno-ugorskaja transkriptsija (FUT) v istoricheskom aspekte i v sopostavlenii s mezhdunarodnym foneticheskim alfavitom (MFA). Tallinn.

Verbov, Grigorij D. 1973. Dialekt lesnyh nentsev. In J. N. Popova (ed.) Samodijskij sbornik. Novosibirsk. 4-190.

Wagner-Nagy, Beáta. 2011. On the typology of negation in Ob-Ugric and Samoyedic languages. Helsinki: Société Finno-Ougrienne.

Zyrjanova, Ekaterina V. 2001. Struktura seljkupskogo glagoljnogo slova v sinhronii i diahronii. Tomsk: TGPU. 